IFN Working Paper No. 1054, 2015

\title{
An Innovation Policy Framework: Bridging the Gap between Industrial Dynamics and Growth
}

Pontus Braunerhjelm and Magnus Henrekson 


\title{
An Innovation Policy Framework Bridging the Gap between Industrial Dynamics and Growth ${ }^{\star}$
}

\author{
Pontus Braunerhjelm ${ }^{1}$ and Magnus Henrekson ${ }^{2}$
}

December 2, 2015

\begin{abstract}
This paper examines policy measures that foster the creation of innovations with high inherent potential and that simultaneously provide the right incentives for individuals to create and expand firms that disseminate such innovations in the form of highly valued products. In so doing, we suggest an innovation policy framework based on two pillars: (i) the accumulation, investment, and upgrading of knowledge and (ii) the implementation of mechanisms that enable knowledge to be exploited such that growth and societal prosperity are encouraged. Knowledge is a necessary but far from sufficient condition for growth. To secure industrial dynamics and growth in the long term, institutions must be designed both to encourage sophisticated knowledge investments and to stimulate the creation, diffusion and productive use of knowledge in all sectors of the economy. We argue that the latter area has been overlooked in the policy discussion and that a coherent innovation policy framework must include tax policy, labor market regulation, savings channeling, competition policy, housing market regulation, and infrastructure to foster growth and future prosperity.
\end{abstract}

JEL Classification: J24, O31, O32, O57.

Keywords: Agglomeration economies, Competition policy, Endogenous growth, Entrepreneurship, Evolutionary models, High-growth firms, Human capital, Incentives, Innovation, Institutions, Innovation policy, R\&D, Systems of innovation, Tax policy, Technology transfer, University-industry relations.

${ }^{1}$ Swedish Entrepreneurship Forum and Department of Industrial Economics and Management, KTH Royal Institute of Technology

Grevgatan 34

S-114 53 Stockholm

SWEDEN

Phone: +46-8-510 65880

pontus.braunerhjelm@entreprenorskapsforum.se
${ }^{2}$ Research Institute of Industrial

Economics (IFN)

P. O. Box 55665

S-102 15 Stockholm

SWEDEN

Phone: +46-8-665 4502

magnus.henrekson@ifn.se

\footnotetext{
* Financial support from Karl-Adam Bonniers Stiftelse, the Jan Wallander and Tom Hedelius Foundation, and the Marianne and Marcus Wallenberg Foundation is gratefully acknowledged. We are grateful for useful comments and suggestions on earlier versions of this paper from Bettina Peters, Scott Stern and the participants at the ZEW Conference National Systems of Entrepreneurship in Mannheim, November 20-21, 2014. This paper is forthcoming in David B. Audretsch and Albert N. Link, eds., Essays in Public Sector Entrepreneurship. New York: Springer.
} 


\section{Introduction}

Often, in their eagerness to get to the "fun stuff" of handing out money, public leaders neglect the importance of setting the table, or creating a favorable environment. ${ }^{1}$

Innovation is increasingly considered the key to elevating prosperity and securing sustainable long-term growth. The last few decades have also witnessed a refinement of previous growth models to include investments in education by individuals and R\&D by firms. Better educated individuals and increased expenditure on $R \& D$ are shown to result in increased innovation and accelerated growth in endogenous growth models. This finding has spurred policy makers, most recently the OECD, the European commission, and other organizations, to design innovation strategies to meet future growth and welfare challenges. Such strategies have also trickled down to the country level.

Similar to the theoretical advances in modelling growth, an increasing number of empirical observations suggest that irrespective of modest R\&D investments, small, entrepreneurial firms substantially contribute to aggregate innovation (Scherer 1965; Klienknecht1989; OECD 2010). These empirical observations indicate that such firms may exploit existing knowledge in different ways compared with older, more mature incumbents. ${ }^{2}$ Moreover, these entrepreneurial firms increasingly emanate from industries that are traditionally considered less innovative, i.e., the service sector. Innovation among service sector firms generate new knowledge that is not necessarily reflected in aggregate R\&D figures, such as new business models and new ways of organizing production, but is of considerable economic significance and rapidly adopted by other firms. Ikea, Starbucks, Ryanair, Virgin, and Walmart, as well as Apple and Microsoft in their early years, are obvious examples of innovative firms that have had a strong impact on the organization of other companies without being heavily committed to research, even though some of them have sizeable design and development departments. This new knowledge is sometimes produced independently and sometimes collaboratively with other firms and organizations. But the innovation process in start-ups radically differs from that in large, R\&D-investing firms (Carlsson et al. 2009). In particular, these findings suggest that innovation and entrepreneurship, whether in incumbents or new start-ups, are inseparable phenomena.

Despite these new insights, the links between microeconomic dynamics and macroeconomic growth are still neither well conceptualized nor adequately modelled. At the micro-level, a patchwork of research contributions stress that entrepreneurship and innovation critically depend on institutions relating to such as education (Kuratko 2005; Béchard and Grégoire 2005), the labor market (Poschke 2013), taxes (Henrekson and Sanandaji 2016), and regional

\footnotetext{
${ }^{1}$ Lerner (2009, p. 12).

${ }^{2}$ As shown by Almeida and Kogut (1997) and Almeida (1999), small firms also innovate in relatively unexplored fields of technology. See also Rothwell and Zegveld (1982), Baumol (2004), and Ortega-Argilés, Vivarelli, and Voight (2009).
} 
dimensions (Saxenian 1994), but this research neglects growth effects. ${ }^{3}$ Mapping this analytically fragmented terrain in a comprehensive framework for growth and combining a dispersed and diverse microeconomic setting with the macroeconomic outcome remains unchartered territory. A constructive attempt to narrow this research gap is provided by Feldman et al. (2015), who distinguish between economic growth and economic development. Economic development, which is claimed to be associated with prosperity and quality of life, is considered a necessary condition for growth. Government policies can support economic development by acting as a "capacity builder" in different dimensions, including in entrepreneurial and innovative aspects. We find the distinction between growth and development promising and side with the view that providing a well-balanced support structure is imperative for entrepreneurship, innovation, and growth. Our approach, however, is considerably more applied, emphasizing how incentives at the individual and firm levels influence macro-level growth in advanced economies where basic institutions such as the rule of law and secure property rights are already in place.

Previous research thus suggests that to facilitate and further enhance the role of entrepreneurs in the innovation process, policies should be expanded to areas other than education and $R \& D$ outlays. Obviously, scientific findings or inventions have little value per se. The policy focus on R\&D to boost innovation tends to neglect entrepreneurial processes where existing (or new) knowledge is combined with individual abilities in the search for new market opportunities. The entrepreneur is thus likely to play a potentially important role in transforming knowledge to growth, but for entrepreneurs to play such a role, the individualopportunity nexus must be acknowledged in the design of policies (Acs et al. 2009; Braunerhjelm et al. 2010).

Consequently, a policy discussion focusing on a limited set of instruments or areas is inadequate. A far more fruitful policy question is the following: What policy measures (i) foster the creation of innovations with high inherent potential and, simultaneously, (ii) provide the right incentives for individuals to create and expand firms that disseminate such innovations in the form of highly valued products?

This essay aims to provide an answer to this two-pronged question. This requires a broad approach; a narrow focus on knowledge creation (i.e., education and R\&D) is insufficient. New knowledge is not automatically disseminated or transformed to innovations, expanding firms and valuable goods and services. Rather, this is conditional on institutions (regarding both policies/rules of the game and organizations) and incentives that promote productive entrepreneurship. A limited number of core policies thus seem critically important.

We stress that recognizing the importance of diffusing and exploiting knowledge investments opens a complementary policy field related to entrepreneurs, the expansion of firms, and the

\footnotetext{
${ }^{3}$ Ample evidence from previous research also suggests that small and new firms provide most of the new jobs and terminate fewer employees than large firms in downturns and that a positive correlation exists between entrepreneurship/small firms and growth (e.g., Braunerhjelm et al. 2010; Thurik and Tessensohn 2012; Haltiwanger et al. 2013).
} 
competence structure of supporting agents (e.g., financial market actors in different phases of the life cycle of the firm, legal advisors, and management specialists). This area of policy has been neglected in a growth context, but it is crucial for understanding the innovation process and the ensuing implications for growth policies (Braunerhjelm 2010).

Drawing on findings in other areas of economics, e.g., monetary and fiscal policies, we emphasize that innovation policies also require a credible and long-term framework that combines different areas of economic policies. Specifically, we suggest an innovation policy framework based on two pillars:

- The accumulation, investment, and upgrading of knowledge. The policy areas involved in this pillar relate to the institutions that are needed to encourage high-quality education at all levels, to prompt internationally leading universities and their research, to establish links between academia and the commercial sector, and to fund universities.

- The implementation of mechanisms that enable knowledge to be exploited such that growth and societal prosperity is encouraged. These mechanisms involve a completely different set of institutions, such as tax policies, the regulatory burden, competition, and the formation of clusters. These mechanisms also include policies that create environments and incentives for individuals to undertake entrepreneurial efforts, innovations, and firm expansion.

We will demonstrate what is required to integrate these two interdependent pillars in a coherent innovation policy framework. Without the accumulation, investment, and upgrading of knowledge, the second set of policies is likely to generate less value. Without the implementation of mechanisms that enable knowledge to be exploited, knowledge investments can be expected to yield little, if any, growth.

The remainder of the paper is organized as follows. In section 2, we discuss why present models do not satisfactorily capture the forces that drive innovation and growth. In section 3 , we argue that growth must be connected to institutions and therefore that the challenge is to provide an institutional framework that connects knowledge and entrepreneurial effort in promoting growth. In section 4, we identify the different agents with complementary competencies that are needed to initiate and sustain an innovation-driven growth process. In section 5, we discuss what we consider to be the most important institutions and policy measures in this respect. Section 6 concludes.

\section{What Drives Economic Growth?}

We will draw on three research fields in explaining why present models do not satisfactorily capture the forces that drive innovation and growth. First, we will refer to previous and current growth models that have dominated in providing a basis for policy prescriptions. Second, the insights from the evolutionary economic models will be utilized. Finally, we consider the systems of innovation (SI) approach. Based on insights from these three areas, we will synthesize the findings regarding the institutional inferences that can be extracted concerning knowledge, innovation, and growth. 


\subsection{Past and Current Mainstream Growth Paradigms}

Despite its advantages with respect to tractability and clarity, the original neoclassical growth model suffered from a major disadvantage: weak empirical support. The limited explanatory power was attributed to the accumulation of capital and labor; instead, an unexplained residual factor was identified as the main driver of economic growth, assumed to consist of new knowledge, both technological and organizational (Solow 1957; Denison 1968).

Obviously, this is an unsatisfactory feature of the neoclassical model because the commercial exploitation of (scientific) ideas always requires resources. Since knowledge exploitation was viewed as "manna from heaven", policy prescriptions focused on optimizing the relationship between capital and labor to obtain equilibrium growth.

Romer (1986, 1990) endogenized investments in knowledge and human capital. Although firms invest in R\&D to obtain a competitive edge, some of this knowledge spills over to a societal knowledge stock that augments productivity in all firms. However, technology is not a pure public good; although a non-rival good, it is partially excludable. Even if capital and labor remain constant, increases in knowledge result in more rapid growth. Policy recommendations center on tax incentives and subsidies to increase knowledge (R\&D) investments, even though empirical support is ambiguous. Rather, empirical studies indicate that knowledge is one, but far from the only, factor driving growth (Barro 1999; Jones 1995, 2011). ${ }^{4}$

Whereas the Romer model starts with a monopolistic market structure, much of the subsequent literature adopts a (temporary) monopoly framework where firms engaged in $\mathrm{R} \& \mathrm{D}$ races to create the next new product, which would give them a monopoly until the next race produced a new monopoly product. In Romer's stylized setting, firms introduce new varieties of goods, diluting profits and decreasing each firm's market share, whereas in the socalled neo-Schumpeterian models, the introduction of new varieties of goods with higher quality implies that firms have captured the entire market. ${ }^{5}$ The monopoly position that firms attain if they succeed allows them to sell their products at prices higher than their production costs and to thereby recover their research outlays.

In the most recent vein of knowledge-based growth models, the focus is narrowed and better defined. Specifically, these models focus on the effects of technology-based entry on the innovativeness and productivity of incumbents and the implications of firm heterogeneity on creative destruction and growth (Aghion and Griffith 2005). ${ }^{6}$

Although the most recent models acknowledge the impact of factors such as competition and entry regulations, innovation is still considered a process where $R \& D$ is converted to new products, often in markets that are characterized by oligopoly or monopoly. Knowledge-based

\footnotetext{
${ }^{4}$ For a detailed account of the weaknesses in the theory building of endogenous growth models, see Braunerhjelm (2011). See also Antonelli (2007) on the "economics of complexity”.

${ }^{5}$ The neo-Schumpeterian models define entrepreneurs either in a very rudimentary way or in a way in which they have a highly specific role, e.g., discovering the next pharmaceutical blockbuster (Aghion and Howitt 1992; Segerstrom 1991; Grossman and Helpman 1991).

${ }^{6}$ See Aghion (2013) for a survey.
} 
growth models are a sizeable step forward in understanding growth. However, the precise microeconomic mechanisms are still constrained by strong assumptions regarding how to define innovations and how innovations are connected to R\&D investment.

\subsection{The Evolutionary Economic Models}

Nelson and Winter (1982) presented the first coherent model of industrial dynamics and growth in evolutionary economics. Their model builds on interacting dynamic processes that govern the way that an economy or an industry evolves. Most prominent among those are the mechanisms ensuring variation in product space, selection (market competition), and knowledge transmission over time (routines). Routines are shown to be cost efficient, but they may change over time, i.e., a routine is characterized as a "pattern of behavior that is followed repeatedly, but is subject to change if conditions change" (Winter 1964, p. 263). ${ }^{7}$ The evolutionary approach emphasizes the central role of a continuous selection of firms and products appearing in the market.

Moreover, scholars in this field have stressed the differences in routines between incumbents investing in $R \& D$ and firms adopting an "entrepreneurial routine" that exploits strategies other than R\&D investments to achieve competitiveness. The chosen routine depends on technological differences across sectors (Dosi 1982; Nelson and Winter 1982; Malerba and Orsenigo 2000). In concentrated sectors characterized by considerable fixed costs, large incumbents drive R\&D-based innovations. Moreover, appropriability conditions are important. Simultaneously, different routines work in sectors characterized by other technological opportunities that are more conducive to entrepreneurial endeavors (Winter 1984; Malerba and Orsenigo 1996).

The evolutionary economics approach includes many properties that characterize real-world economies, such as path dependence, adaptivity, feed-back mechanisms, and varying firm age and size. Still, the models are vague regarding policy conclusions, and they are more concerned with determining how industries and technologies evolve over time than with identifying policies that promote growth and social welfare.

\subsection{The Systems of Innovation Approach}

A parallel literature - the SI literature - has had a considerable impact, although it is disconnected from the growth literature. ${ }^{8}$ The SI approach emphasizes the necessary building blocks for innovation, the interaction between them, and the key players in the innovation system. Therefore, the organizational structure and composition of systems are emphasized, where government organizations or semi-public bodies often are the centerpieces.

A major weakness is that the SI literature rarely considers the market mechanism and the importance of the incentive structure. Instead, the innovation process is analyzed, often with

\footnotetext{
${ }^{7}$ See Orsenigo (2009) for a survey.

${ }^{8}$ The seminal studies are Freeman (1987) and Lundvall (1992). The concept originates in List’s (1841) “national production systems”.
} 
an emphasis on the importance of interactive learning among key agents. The profit-driven firms or entrepreneurs that are the vehicles for transforming knowledge into innovation and welfare-enhancing goods and services are basically absent. The policy focus is on interventionist technology measures, predominantly with a national perspective, despite the increasingly global character of knowledge. Competition is viewed with skepticism. ${ }^{9}$

The solutions proposed within the SI approach are often referred to as institutions by its proponents. Still, the term "institutions" is almost always used as a synonym for the organizations constituting the system rather than "the rules of the game in society" (North 1990). Edquist (2011) argues that the institutions in the latter sense should be included. He claims that (p. 1739) “... it is important to ascertain that existing institutions are appropriate for promoting innovation and to ask the same question of how institutions should be changed or engineered to induce innovations of certain kinds." However, Edquist provides no indication regarding how pertinent institutions should be designed to promote innovation.

Edquist (2011) also asserts that the performance of an innovation system should be measured, but according to him (p. 1741), “output is—simply_innovations.” As empirical proxies, he suggests the share of firms that have introduced a process or product innovation in the last three years (new to either the firm or the market) and the share of total turnover attributable to new or significantly improved products. The difficulties in measuring innovation are well known, and subjective evaluations by incumbent firms can be questioned for numerous reasons. ${ }^{10}$ Thus, the extent to which these innovations translate into economic activity through entrepreneurship is ignored; individual agency is ignored. ${ }^{11}$ Neither is the feedback from the rate of return on innovation leveraged by entrepreneurship back to new innovation (Holcombe 2003) discussed.

Fig. 1 Economic Growth and the Rate of Innovation in EU Countries, 2006-2010.

\section{Enclosed}

Source: Braunerhjelm (2012).

Yet, we share the conclusion drawn from the SI approach that investment in R\&D alone is insufficient to boost innovation, and the lack of a positive correlation between aggregate measures (as measured by the EU Innovation Index) of innovation and growth (Figure 1) at the macro-level supports the insufficiency of such a strategy.

Acs et al. (2014a, p. 479) instead propose a "National System of Entrepreneurship” approach:

\footnotetext{
${ }^{9}$ In his survey of the extensive research on SI, Carlsson (2007) shows that the overwhelming majority of studies address invention rather than innovation, and no more than two to three percent of the studies surveyed discuss entrepreneurship. Less than three percent of the SI studies address output criteria such as the effect on productivity, rate of growth, rate of innovation, and patenting.

${ }^{10}$ See Gault (2013), Hall (2011), and OECD (2010) for reviews of the literature. Hall's preferred measure of innovation is TFP growth.

${ }^{11}$ Hung and Whittington (2011) is a partial exception, although their point is somewhat different. Hung and Whittington indicate that SI can become self-reproducing "systems of inertia”, which can sometimes be escaped through institutional entrepreneurship.
} 
A National System of Entrepreneurship is the dynamic, institutionally embedded interaction between entrepreneurial attitudes, activities, and aspirations, by individuals, which drives the allocation of resources through the creation and operation of new ventures.

This approach is a considerable improvement over the SI approach, but in our view, it is insufficient. The institutional variables that are used, such as technology absorption, gender equality, R\&D spending, and depth of capital markets, are not institutional variables; they are outcomes resulting from the evolution of the economic system in a given institutional setup. Although Acs et al. focus on key components of the system, a more explicit analysis of key institutions governing the incentives of the individuals and organizations involved in the innovation and subsequent entrepreneurial exploitation is necessary.

\section{Linking Growth to Institutions}

Where does this brief account of the major theoretical contributions leave us concerning implications for policy and institutional design? The theories differ in their policy priorities, each focusing on a limited number of growth stimulating measures. However, the policy conclusions are derived from a highly stylized setting whose definition requires both strong assumptions and the exclusion of pertinent aspects. Innovation requires a broader perspective than policy aimed at knowledge investment, encompassing the entire spectrum of processes and activities involved - from basic schooling to research, innovation, entrepreneurial venturing, and large-scale industrial production and distribution.

The decisive role of institutions protecting ownership and providing a "rule of law" for society has been convincingly demonstrated (North 1990; de Soto 2000; Baumol 2002; Rodrik et al. 2004; Acemoglu and Johnson 2012). Our analysis pertains to high-income countries where the rule of law applies, where private property rights are reasonably secure, and where financial markets are deregulated. Therefore, we will not address these factors further. Rather, we will focus on the determinants for how new discoveries - and new combinations of old discoveries - are transformed into innovations and subsequently are converted to new and growing firms. To obtain the full social benefits of knowledge, we identify the institutions that are required to attain a general level of knowledge necessary to be globally competitive and to diffuse this knowledge in the form of innovative entrepreneurship and high-growth firms (HGFs).

The subsequent analysis will clarify that, for example, even if financial markets are fully deregulated, other institutions, such as the tax system or rules governing pension savings schemes, may influence how well financial markets can fulfil their role in financing innovative entrepreneurship. A general conclusion is that multiple institutions interact in complex ways, either reinforcing or abating the total effect.

Generally, we agree with, among others, Baumol (2010), Lazear (2005), and Carree and Thurik (2010) that entrepreneurship or the entrepreneurial function can effectively be considered a distinct factor of production. In line with Wennekers and Thurik (1999, p. 4647), we define entrepreneurship as the ability and willingness of individuals, on their own or in teams, inside and outside existing organizations to 
- perceive and create new economic opportunities (new products, new production methods, new organizational schemes, and new product market combinations) and

- introduce their ideas in the market, in the face of uncertainty and other obstacles, by making decisions regarding location, form, and the use of resources and institutions.

In addition, we postulate that entrepreneurs should have ambition to grow the resulting venture.

The entrepreneur often "creates" the capital of the firm by investing in tangible and nontangible assets that, in time, create a return, such as developing a product and building firm structures. This capital requires a continued commitment on the part of the entrepreneur. The entrepreneur is rewarded for exerting effort and for postponing the consumption of firm equity into an uncertain future. Successful entrepreneurial firms require several components that are difficult or nearly impossible to purchase externally, such as product or business ideas, sufficient managerial skills to implement innovations, and commitment to exert time and effort to realize an uncertain outcome.

The challenge is to provide an institutional framework that connects knowledge and entrepreneurial effort in promoting growth. To facilitate such a connection, the Schumpeterian entrepreneur must be given a central role in the growth process. Uncertainty, search, and experimentation are crucial aspects of the innovative process, and the outcome of this process is determined by a combination of the individual's cognitive and non-cognitive abilities and the given opportunity space, the latter of which is shaped by the institutional system. Disregarding these aspects indicates that substantial knowledge creation concerning innovation and economic growth is neglected.

\section{Key Agents in Turning Knowledge into Entrepreneurial Venturing and Large-Scale Production}

To create a large knowledge base that translates into significant knowledge-based commercial activity, many crucial steps are involved. Fundamentally, the right incentives must be in place at all levels for individuals to invest in valuable human capital. We will return to the incentive structure in detail in Section 5. In this section, we will discuss the individual's choice, the key actors, and the importance of matching the right competence provider with the firm's needs in different phases of the entrepreneurial process.

\subsection{From Educational Choice to Knowledge-Based Entrepreneurship}

Successful entrepreneurs in the U.S. tend to have a far more advanced education than average, and they must be able to recruit highly competent people to grow their firms. ${ }^{12}$ Potential entrepreneurs face several educational and career choices, especially early in life. If the incentives to seek advanced education are weak or erroneous, individuals risk making choices

\footnotetext{
12 See Henrekson and Sanandaji (2014), and the references in Sanandaji (2011).
} 
at many junctures that render acquiring the type of knowledge that is valuable to entrepreneurial firms more difficult.

The first strategic choice facing an individual occurs in high school when the individual decides whether to enter the labor market or to proceed to university. If the individual enrolls in a university, he or she faces a choice between science- and technology-based disciplines (or STEM fields-science, technology, engineering, and math) ${ }^{13}$ and other areas. At graduation, the natural science graduate can again choose between employment and graduate studies with the objective of obtaining a Ph.D. After receiving a Ph.D., the individual faces yet another choice between a university career and other employment. ${ }^{14}$

Successful entrepreneurial ventures are often highly dependent on academically trained and motivated individuals. Several other sources are important for recruiting people to knowledge-based entrepreneurship, such as the pool of individuals with either a graduate or an undergraduate degree, individuals with such an educational background working at other firms, and, in some cases, even university faculty.

Figure 2 shows that many links must function efficiently for knowledge-based entrepreneurship to flourish. First, incentives to invest in human capital at the university level must be present (1a, 1b, 1c). Second, incentives to become involved in knowledge-based entrepreneurial ventures must exist (2a, 2b, 2c, 2d, 2e). Third, incentives in the university system must be present to adjust the lines of study to demand in the private sector and to facilitate the transfer of knowledge from academia to the entrepreneurial sector. This third factor can be expected to have complex repercussions throughout the entire decision tree depicted in Figure 2. The incentives in the university system will directly influence the propensity of faculty to become involved in entrepreneurial ventures (2a), but it will also affect students' educational choices (1b, 1c, 3).

Fig. 2 From Educational Choice to Knowledge-Based Entrepreneurship

\section{Enclosed}

Source: Henrekson and Rosenberg (2001).

Thus, it must be beneficial to acquire productive knowledge that is subsequently used intensely. Income taxes, wage differentials, a well-designed social insurance system, and an efficient service sector facilitating specialization are important components that we will address below.

\footnotetext{
${ }^{13}$ Recent research has documented that worker knowledge in the STEM fields is particularly important for economic growth. This result also holds for workers without a college degree. See Rothwell (2013) for an overview.

${ }^{14}$ The evidence suggests that, in most cases, it is not advisable for faculty to become entrepreneurs. There are few cases where faculty have transitioned to an entrepreneurial career with great success (Åstebro et al. 2013). Instead, it is often preferable for former students to start firms and for faculty members to assume advisory positions in these firms.
} 


\subsection{From Innovation to Large-Scale Production: The Crucial Agents}

The development of a successful firm requires the combination of many complementary agents - a competence structure-each contributing key competencies. Entrepreneurship is vital, ${ }^{15}$ but other agents, including early stage financiers (business angels and venture capitalists), industrialists, inventors, innovators, skilled labor, competent customers, actors on secondary markets (notably buyout firms, portfolio investors, and management buy-ins), and other support agencies, are also important. See Figure 3. Successful venturing that generates rapid growth is a function of how well the different agents acquire, update, and jointly use their respective competencies. The opportunities and incentives for success are largely determined by the institutional structure.

The first phase of commercialization (introduction and early growth of firms) involves entrepreneurs, whereas skilled workers often are involved only to a small extent. Industrialists are active in the phase of industrialization and rapid growth, which requires a significant amount of skilled labor. Business angels and venture capitalists are important financiers in the earlier phases. In later phases when the firm is larger, agents in secondary markets also play the role of financier. Figure 3 is a simplification. For example, industrialists and secondarymarket agents may also be involved in an earlier stage, and one person can fill several functions. Competent customers are typically involved in all phases, and they ultimately (with other customers) determine the demand for goods.

Fig. 3 The Roles and Interaction of Different Agents in the Commercialization Process

\section{Enclosed}

Source: Henrekson and Johansson (2009).

The development of a successful firm thus requires many key actors with complementary competencies who interact to generate, identify, select, expand, and exploit new ideas to satisfy consumer preferences more efficiently. ${ }^{16}$ When the competence structure is complete, the complementary competencies of these actors will produce a dynamic process of creative destruction—channeled through firm entry, expansion, contraction, and exit—which causes structural transformation in the perennial struggle between new and old structures.

Successful entrepreneurship and firm growth are a function of how well these actors, with their different skills and competencies, acquire and use their competencies in ways that render reaping the benefits of the complementarities possible. To exploit complementarities, appropriate institutions that harmonize the incentives of the different types of actors are

\footnotetext{
${ }^{15}$ The introduction of new ideas to and the (possible) subsequent development of the original innovations in large-scale businesses generally require two separate competencies (Baumol 2004).

${ }^{16}$ To our knowledge, the idea concerning the importance of complementary competencies to generate growth was first recognized by Gunnar Eliasson (e.g., Eliasson 1996). Henrekson and Johansson (2009) explicitly use this framework to analyze the effects of a wide array of policies on high growth firms (HGFs).
} 
necessary. Hence, different skills and expertise with an institutional structure conducive to risk taking and experimentation are required.

Figure 4 outlines the central phases in the evolution of an entrepreneurial firm in the typical case when the founder-entrepreneur does not have sufficient funds of his own to finance the development of the firm until it can be sold to outside parties.

A new firm based on a unique idea is typically started by one or several founders who are carriers/owners of the innovation and the concomitant tacit knowledge necessary to launch the firm. If a firm is in a high-tech sector or if the firm is based on a truly novel idea, the risk associated with engaging in a new venture is extremely high. ${ }^{17}$ Even when the firm is eventually a success, it usually takes a long time before the finished product is introduced to the market and longer still before the cash flow becomes positive. In each phase, typical problems must be managed. ${ }^{18}$ The risks involving innovative entrepreneurship are rarely calculable by either the founder or external investors (Knight 1921). This situation contrasts with portfolio investments in public firms where historical data offer a basis for calculating the expected risk-return relationship.

Fig. 4 Central Phases in the Evolution of an Entrepreneurial Firm

\section{Enclosed}

Source: Henrekson and Sanandaji (2016).

A production factor that is used in a certain highly specialized activity is relation specific, i.e., it can rarely be reallocated to another activity without incurring substantial costs (Caballero 2007). Thus, the value of such a production factor is contingent on its continued use in precisely its specialized activity, i.e., where it has developed and honed its unique competencies.

For our purposes, the most relevant example of relation-specific assets arises when an entrepreneur/founder starts financing his firm by raising equity from external investors. Because of the founder's superior information, specialist knowledge, and de facto control of the company, the investors' investment becomes non-fungible. The value of the external investors' equity would decrease significantly if they ousted the founder. Moreover, the founder must recruit key personnel who will make highly relation-specific human capital investments.

The high degree of uncertainty and asset specificity in innovative entrepreneurial ventures render formulating explicit contracts that provide all parties the right incentives to build relation-specific assets virtually impossible. It becomes especially important to protect oneself

\footnotetext{
${ }^{17}$ Three-fourths of all American entrepreneurs receiving VC funding ultimately get a zero rate of return (Hall and Woodward 2010).

${ }^{18}$ Much has been written about the challenges and vagaries facing entrepreneurial firms and the high risks involved. See Gompers and Lerner (2001) for an easily accessible text.
} 
against opportunistic behavior by other parties, e.g., the risk that the founder or other key personnel are outmaneuvered by the external owners and forced to leave the firm prematurely. ${ }^{19}$

Therefore, contractual devices that make ownership and control contingent on (unpredictable) future outcomes are decisive for orchestrating entrepreneurial success. The high transaction costs and non-calculable risks often necessitate equity financing. ${ }^{20}$ Further, very few founders have the financial means to finance the venture until the point at which the cash flow turns positive or the degree of uncertainty has fallen sufficiently to make the firm creditworthy. One way to compensate for these problems is soft loans from public bodies. However, scientific evaluations of such schemes are seldom encouraging. ${ }^{21}$ One reason for the weak scientific support for these schemes is that politicians are often tempted to establish such programs to solve other pressing problems, such as helping an ailing industry or an impoverished region.

As will be discussed more fully below, appropriately designed stock options are a powerful instrument to build firms and attract and retain key personnel. However, the use of stock options presupposes appropriate tax rules.

\section{Key Institutions in Linking Knowledge to Innovative Entrepreneurship and Growth ${ }^{22}$}

Wealthy countries have factors that are customarily identified to be crucial for development, such as the right to education, the rule of law, reasonably secure private property rights, and well-functioning financial markets. ${ }^{23}$ Thus, further discussing these factors is unlikely to substantively advance our understanding of the effects of institutions on entrepreneurship and innovation-based firm growth.

We emphasize a selected number of institutional areas that we define as particularly important for promoting innovation, entrepreneurship, and, ultimately, growth. In selecting these areas, we start out from our two building blocks of growth: knowledge and the diffusion of knowledge. This approach leads us to examine skills and human capital (education and research, i.e. the knowledge base), the labor market (diffusion and allocation of knowledge), other regulations (diffusion of knowledge and entry barriers), taxes (incentives to invest in education and enterprising), financing (diffusion of knowledge and entry barriers), and agglomeration (diffusion of knowledge).

\footnotetext{
${ }^{19}$ For an in-depth analysis of the effects of incomplete contracts, see Bolton and Dewatripont (2005, Ch. 11).

${ }^{20}$ Debt financing is problematic in this case, since firms have neither assets that can be used as collateral nor a positive cash flow. Asymmetric information and the tendency among entrepreneurs to overestimate the future prospects of their startups also contribute to the difficulties of obtaining bank financing.

${ }^{21}$ See Lerner (2009) and Sandström et al. (2014) for a survey of the literature.

${ }^{22}$ Research on the welfare effects of regulations or institutions originated in Pigou's (1938) work on "public interest theory". The basic idea is that unregulated markets will give rise to market failures that require the imposition of regulations. Subsequent research has questioned these insights (Coase 1960). In particular, public choice theory has emphasized the negative effects of vested interests, rent seeking, and regulatory capture (Tullock 1969; Stigler 1971; Peltzman 1976).

${ }^{23}$ See Rodrik et al. (2004) and Levine (2005).
} 
Below, we discuss the most relevant policies and institutions in detail. Throughout this discussion, we try to remain concrete and to connect the discussion to the analysis of different models and approaches above.

\subsection{Incentives in the Educational System ${ }^{24}$}

Policies intended to facilitate technology transfer exist in the larger context of their respective university systems. In contrast to the university systems in most European countries, the American university system is decentralized and intensely competitive. American universities retain a high degree of autonomy; thus, they can pursue opportunities to solve their own problems and to build on their own unique strengths and aspirations. Competition occurs along several dimensions: (1) competition among universities for students and, at the graduate level, among professors for the best students; (2) competition among universities for the best professors in a cultural and economic context where mobility is high; and (3) competition among professors for research support, which provides time away from teaching and access to complementary resources.

The U.S. university system thus seems more responsive to the economic needs of society than the university systems in most European countries. To justify high tuition fees, students expect a high degree of relevance of the offered curricula. Likewise, professors who are dependent on research are more likely to adjust their research to fields that have high economic value (Rosenberg 2000).

Decentralization and competition in the American system result in greater salary dispersion, where salary differences likely reflect the economic relevance of the professor's field and his/her achievements in research and teaching. Entirely new fields and major breakthroughs in established fields have been rapidly introduced to the curricula of leading U.S. universities over the years.

By contrast, most European university systems are highly centralized. Universities tend to be government owned, and entry of private universities is disallowed or highly restricted. The government typically grants charters to universities and determines the rules of admission and the size of universities (through budgetary allocations), as well as the size of specific fields of study. Such control permits less flexibility for individual institutions to allow remuneration to track an individual professor's research and teaching performances more closely and to vary the level of remuneration according to the economic value of the professor's field. Greater centralization also renders adjusting the allocation of research budgets across fields in response to changing demand outside the university more difficult for individual universities. $^{25}$

\footnotetext{
${ }^{24}$ This section draws on Henrekson and Rosenberg (2001, section 1).

${ }^{25}$ For an example, see Jacobsson et al. (2001) who document the slow response of the Swedish university system to the sharp increase in demand for training in electrical/electronic engineering and computer science in the 1970s and 1980s.
} 
With respect to the specific role of universities as suppliers of trained personnel in appropriate fields of study, timing is crucial. In competitive world markets, large economic rents are commonly available to those firms (and those countries) that can quickly respond to economic opportunities that are created by new technologies or new disciplines. Late arrivals are likely to find that the large financial rewards have already been acquired because competitive forces have driven down prices.

In European countries, university degree requirements are typically formulated as a fixed program rather than a flexible accumulation of requirements and credits, as in the U.S. In the European system, making changes is therefore more difficult.

\subsection{The Tax System}

The extent and design of the tax system affects the net return to entrepreneurship both directly and indirectly. The tax system determines a potential entrepreneur's risk-reward profile and, consequently, his or her incentives for undertaking entrepreneurial activities. Even if nonpecuniary rewards that are unaffected by taxes (such as autonomy and individual flexibility) also matter, the financial effects of taxation cannot be neglected. Extensive research has analyzed the theoretical and empirical effects of the tax system; however, its effects are often complex and sometimes counter-intuitive.

From a theoretical point of view, the tax system affects entrepreneurial activity through a variety of mechanisms. The theoretical literature identifies four main effects: (1) an absolute effect influencing the supply and effort of potential entrepreneurs in the economy; (2) a relative effect influencing an individual's choice of occupation and organizational form; (3) an evasion effect influencing the willingness to become an entrepreneur to exploit opportunities to decrease the tax burden; and (4) an insurance effect influencing the amount of risk that people are willing to assume and, therefore, the likelihood that people undertake entrepreneurial activities.

The absolute effect renders starting or expanding a business more expensive; an absolute increase in the taxation of entrepreneurs lowers the (expected) after-tax reward. Increased taxation also makes expansion financed by retained earnings more difficult and negatively affects the liquidity position of entrepreneurs. Lower after-tax returns and higher expansion costs discourage entrepreneurial activities and impede the emergence of new start-ups and the expansion of firms. ${ }^{26}$

Taxation may also alter the relative return of different activities if it favors one form of employment over another. Thus, a higher tax rate may encourage income shifting and may positively influence (some form of) entrepreneurship in the economy.

\footnotetext{
${ }^{26}$ See, e.g., the discussion in OECD (1998).
} 
The evasion effect arises if evading taxes on entrepreneurial income either illegally or legally is easier than paying them. Evading taxes is often easier for self-employed entrepreneurs; ${ }^{27}$ self-employed entrepreneurs may be able to underreport income by neglecting to register cash sales, overstate costs by recording private expenses as business costs, or use informal agreements that are difficult for the tax authority to verify. ${ }^{28}$ Higher taxes may therefore encourage self-employment. When a business expands above a certain level, it becomes more difficult to exploit tax avoidance opportunities.

Finally, regarding the insurance effect, taxation (with full loss offset) functions as insurance that stimulates risk taking (Domar and Musgrave 1944). With respect to entrepreneurship, increased tax on the net return with full loss offset will reduce the after-tax variance of profits and therefore the risk associated with the business. If potential entrepreneurs are risk averse, this risk reduction may stimulate entrepreneurship. ${ }^{29}$ The insurance effect also assumes a proportional tax rate with full loss offset. Given that entrepreneurial income is more variable than salaried income, the average tax will be higher for entrepreneurs in a progressive tax system. A progressive tax system with imperfect loss offset therefore deters entrepreneurial business entry (Gentry and Hubbard 2000).

Many studies in this field often analyze the effect of a specific tax, such as the tax on earned income. One should analyze taxes on entrepreneurial income, however. Yet, no specific tax on income from entrepreneurial effort exists in practice. From a tax perspective, entrepreneurial income can be taxed in many different forms, including labor income, business income, current capital income (dividends and interest), or capital gains. These taxes may affect entrepreneurial activities differently. A thorough analysis of the effects of taxation on entrepreneurship must disentangle these effects.

Moreover, much of the entrepreneurial function is conducted by employees without an ownership stake in the firm, for whom the earned income tax schedule is applicable. For these categories, a high tax on earned income may have negative incentive effects on entrepreneurship.

Regarding capital and corporate taxation, a high tax rate on business profits discourages equity financing and encourages debt financing (Desai et al. 2003; Huizinga et al. 2008). To the extent that debt financing is less costly and more available to larger firms, high corporate tax rates coupled with tax-deductible interest payments disadvantage smaller firms and potential entrepreneurs (Davis and Henrekson 1999). Taxing corporate profits also reduces the amount of retained earnings that can be used to expand the existing venture. Further, taxing profits in small firms often leads to lower growth rates (Michaelas et al. 1999). A high

\footnotetext{
${ }^{27}$ See, e.g., Long (1982) and Pestieau and Possen (1991) for a discussion of tax evasion and choice of occupation. Robson and Wren (1999) conclude that the average tax rate affects evasion behavior.

${ }^{28}$ A Swedish study estimates that the self-employed underreport their income by 30 percent (Engström and Holmlund 2009).

${ }^{29}$ A recent discussion of this effect is provided by Cullen and Gordon (2007). In practice, no tax system has full loss offset.
} 
tax rate on dividends encourages the reliance on retained earnings for financing expansion. Such a tax rate punishes new ventures, locks in retained earnings, and traps capital in incumbent firms. Therefore, a high tax rate on dividends obstructs the flow of capital to the most promising projects because it favors incumbent ventures (Chetty and Saez 2005).

Most of the economic return from successful high-impact entrepreneurial firms materializes as steeply increased market value rather than dividends or large interest payments to the owners. Thus, the taxation of capital gains on stock holdings greatly affects the incentives for potential high-impact entrepreneurs (Cumming 2005; Da Rin et al. 2006). Successful entrepreneurs are also highly sensitive to wealth, property, and inheritance taxes. ${ }^{30}$

Stock options can be used to encourage and reward individuals who supply key competencies to a firm. In ideal circumstances, stock options provide incentives that closely mimic direct ownership. The efficiency of stock options greatly depends on the tax code. If gains on stock options are taxed as wage income, some of the incentive effect is lost-particularly if the gains are subject to (uncapped) social security contributions and if the marginal tax rate on wage income is high.

The situation changes dramatically if an employee with stock options can defer the tax liability until the stocks are eventually sold. The effectiveness is further reinforced if the employee suffers no tax consequences on the granting or the exercise of the option and if the employee is taxed at a low capital gains rate when the acquired stock is sold (Gilson and Schizer 2003).

The tax systems of many countries evolved before complicated ownership structures involving private equity (venture capital [VC] and buyout firms) financing existed. Private equity (PE) ownership involves layers of ownership: private ownership stakes by founders and key personnel; an ownership share by the PE firm; an ownership stake by PE partners (often indirect); an investor stake in the PE fund; and final beneficiaries of institutions investing in PE funds. Sophisticated mechanisms were initially needed to provide highpowered incentives for many actors in addition to the final equity holders. In fact, the modern VC industry in the U.S. could not evolve until the tax system was changed in key respects. Sharp reductions in the capital gains tax and stock option legislation in 1981 allowed the tax liability to be deferred to the point when stocks were sold rather than when the options were exercised. In addition, new legislation in 1979 allowed pension funds to invest in high-risk securities that were issued by small or new companies and VC funds (Misher 1984; Fenn et al. 1995).

To calculate the total effect of taxation, one must consider the specific rules for depreciation and valuation in corporate taxation and the taxation of interest income, dividends, capital

\footnotetext{
${ }^{30}$ Certain assets are exempted from taxation in many countries, such as corporate wealth or pension savings, and the imputed value used as the basis for assessments is often based on arbitrary accounting rules. These rules may encourage (such as the corporate wealth exemption) or discourage (such as the pension savings exemption) investments in entrepreneurial activities. See Rosen (2005) for an overview.
} 
gains, and wealth. The effective total tax rates also depend on the ownership category. ${ }^{31}$ In many developed countries, business ownership positions that are directly held by individuals and families have been taxed more heavily than other ownership positions. The wave of tax reforms that swept the OECD in the 1980s resolved many of these differences. ${ }^{32}$ The differences that still persist, however, provoke an endogenous response in the ownership structure of the business sector to the tax-favored owner categories. ${ }^{33}$ If individual stock holdings are disfavored relative to institutional holdings and if institutions are less willing to invest in small and new entrepreneurial projects, entrepreneurial activity would be discouraged. $^{34}$

Table 1 summarizes our analysis of the tax system and outlines a tax system design that promotes innovative entrepreneurship.

Table 1 Key Characteristics of a Tax System Favoring Innovative Entrepreneurship

\begin{tabular}{l}
\hline Type of tax \\
\hline Low personal tax on capital income \\
Low personal tax on long-term capital gains \\
Low tax on stock option gains not due until eventual exit \\
Tax neutrality across owner categories \\
Tax neutrality across sources of finance \\
No wealth taxation of asset holdings or exemption for equity holdings \\
Effective corporate tax rate neutral across types of firms and industries \\
Symmetric tax treatment of profit and losses
\end{tabular}

\subsection{The Organization of Labor Markets}

The way that labor markets are organized and regulated affects labor mobility. This effect on labor mobility may have repercussions for unemployment, workforce participation, and aggregate demand, which in turn may affect growth. Moreover, labor mobility may effect productivity and innovation. Caballero and Hammour (2000) stress that "constrained contractual capabilities" in labor markets (and in the financial system) may inhibit the process of creative destruction. ${ }^{35}$

Mobility increases productivity at the firm level (Nicoletti and Scarpetta 2003; Bassanini et al. 2009; Andersson and Thulin 2008). The proposed reasons for this increased productivity are a

\footnotetext{
${ }^{31}$ These types of highly complicated estimates have been made for many countries using the methodology developed by King and Fullerton (1984).

32 Jorgenson and Landau (1993).

${ }^{33}$ Rydqvist et al. (2014).

${ }^{34}$ Henrekson and Johansson (2009).

${ }^{35}$ See also Djankov et al. (2002), Desai et al. (2003), and Shleifer et al. (2008).
} 
better match between firms' needs and the skills of labor (Bessen and Maskin 2009), the spillover of knowledge embodied in labor, and extended externalities related to network spillovers (Powell et al. 1996, Zucker et al. 1998; Song et al. 2003; Hoti et al. 2006). As new knowledge, embodied in labor, enters the firm, established processes and methods are challenged. New knowledge provides new insights, increases efficiency and productivity, and leads to potential new business opportunities.

A recent empirical strand in the literature specifically examines how innovation performance (defined as patent applications) is affected by labor mobility. Kaiser et al. (2015) and Braunerhjelm et al. (2014), implementing similar employer-employee datasets for Denmark and Sweden, conclude that firms' innovative performance is considerably improved as labor mobility increases. Overall, research in this field, although limited, suggests that labor mobility has a positive effect on invention and innovative behavior. ${ }^{36}$

Scarpetta and Tressel (2004) present evidence suggesting that labor market regulations negatively influence the incentives to engage in innovation and technology, which can be expected to have a negative effect primarily on innovation in smaller firms. Micco and Pagès (2006), Autor et al. (2007), and Kugler and Pica (2008) all report a slower restructuring of the economy and a negative impact on entry when labor markets are more regulated. Similarly, studies on the determinants of foreign direct investments find a negative effect of regulated labor markets (Jarvorcik et al. 2006; Gross and Ryan 2008).

Entrepreneurs establish new firms to commercialize new combinations. If successful, these firms expand, while others will stagnate or exit. Similarly, existing firms are continuously challenged by — and challenge — new and existing competitors. If successful, these firms expand, if not they contract and eventually exit. This dynamic process of creative destruction—channeled through firm entry, expansion, contraction and exit—causes structural transformation. A successful economy ultimately exhibits disproportionate growth of highproductivity firms relative to other firms.

Extensive churning is a pervasive trait of all OECD economies (Martin and Scarpetta2012). Remarkably, 80 percent or more of the reallocation of workers occurs in narrowly defined sectors of the economy in developed countries (Caballero 2007). There are two basic drivers for this reallocation: (i) adjustment among firms with different technologies and (ii) experimentation with improved products, management, and so forth. Moreover, excess job reallocation rates are higher for newer firms because of greater uncertainty, more experimentation, and higher variance in the quality of the goods produced.

The empirical findings regarding churning and restructuring provide evidence that strict employment security provisions and other regulations that restrict contracting flexibility are more harmful to enterprises that would like to grow rapidly than to mature firms and firms without growth aspirations. Both the rate at which workers separate from jobs and the rate at

\footnotetext{
${ }^{36}$ One exception is Cassiman et al. (2011) who show that participation in joint ventures is more conducive to innovation than labor mobility.
} 
which employers eliminate job positions decline with the size, age, and capital intensity of the employer (Bartelsman et al. 2004). Hence, a low level of labor market regulations increases the flexibility of high-risk entrepreneurial companies, rendering the evolution of new companies to HGFs more likely. Figure 5 illustrates this tradeoff by depicting the relationship between the strictness of employment protection and the rate of high-growth expectation, early stage entrepreneurship. The figure clearly shows that stricter employment protection is associated with a lower share of early stage entrepreneurship.

Fig. 5 Strictness of Employment Protection and High-Growth Expectation, Early Stage Entrepreneurship

\section{Enclosed.}

Note: Employment protection refers to the 2004 OECD index (version 2), and high-growth expectation, early stage entrepreneurship is the average over the 2004-2009 period according to the Global Entrepreneurship

$$
\text { Monitor (GEM). } \mathrm{R}^{2}=0.57
$$

Source: Bosma and Levie (2010).

Generous, far-reaching employment protection legislation increases employees’ opportunity cost of changing employers or leaving a secure salaried job to become an entrepreneur. Given that initiatives resulting in HGFs often require a change of workplace, far-reaching employment protection legislation should be avoided.

Additionally, very small firms may be able to avoid unionization and the signing of collective agreements, and they therefore benefit from greater freedom of contracting. Such freedom is likely lost once the firm size exceeds a certain threshold. Therefore, these evasive measures do not help HGFs and are not instrumental in promoting welfare-enhancing structural transformation.

Wage-setting institutions may affect the scope of cooperation among key actors with complementary competencies, the conditions for (potential) HGFs, and structural transformation through several channels. In particular, the wage compression associated with centralized wage bargaining is likely to disadvantage potential HGFs. An artificially compressed wage structure impedes profitable firms with high productivity from using salaries as an incentive to recruit new productive employees, making expansion more difficult. Minimum wages set above the market equilibrium level, on the other hand, force low-profit firms with low productivity out of business. Indeed, Halabisky et al. (2006) demonstrate that HGFs are low-salary companies at the beginning of their life cycle and that large firms in slowly growing industries are high-salary companies. When young potential HGFs realize their growth potential and begin to grow rapidly, salaries start to grow quickly. This finding suggests that a compressed wage structure that maintains minimum wages above the market equilibrium level tends to choke potential HGFs in their infancy. Potential HGFs have difficulties bearing high wage costs early in their life cycle when they are still developing their product and are in the early phase of commercialization.

Given the large intra-firm differences in productivity, especially in young and rapidly expanding industries and firms (Caballero 2007), the cooperation among the key actors 
needed for HGFs is impaired if wages are set in negotiations far from the individual workplace and if the above issues are therefore not properly considered.

\subsection{Institutions Providing Insurance and Governing the Channeling of Savings}

Sinn (1996) formally demonstrates that by providing insurance for unfavorable outcomes, an extensive and generous public social insurance system can theoretically encourage individuals to pursue entrepreneurial endeavors, but to our knowledge, this hypothesis has yet to be tested empirically. A generous welfare system would seemingly make it less costly to bear uncertainty as an entrepreneur or to move to a risky job in an entrepreneurial firm. In labor markets where job security is closely linked to job tenure, the effect of a generous welfare system may no longer hold. What matters is the opportunity cost, i.e., how much income security an employee must surrender if she transfers to self-employment or a risky job in an entrepreneurial firm. For a tenured employee with a low-risk employer, the opportunity cost rises considerably in many OECD countries.

In many countries, important benefits are connected to employment, such as health insurance in the U.S. Many workers and potential entrepreneurs become "trapped" in large companies that provide generous health insurance for the employee and his/her family. Decoupling health insurance from employment would increase labor flexibility and reduce fears of losing adequate health insurance and other important benefits that may be attached to employment. In Denmark, generous welfare systems are combined with weak job security mandates, sometimes called "flexicurity" (Andersen and Svarer 2007). This situation can be contrasted with the situation in Sweden, where somebody who voluntarily gives up a tenured position for self-employment may not have any more security than that provided by (means-tested) social welfare. Public income insurance systems combined with employment protection legislation tend to penalize individuals who assume entrepreneurial risk. Hence, the opportunity cost of resigning a tenured position is substantially lower in Denmark than in Sweden.

Furthermore, the way that savings are channeled to various investment activities influences the type of business organization that can obtain credit. Pension funds are less likely than business angels or VC firms to channel funds to entrepreneurs. Therefore, the composition of national savings is not neutral in its impact on entrepreneurship and business development. If the government forces individuals to keep a large part of their savings in a national pension fund, the availability of small business financing will suffer relative to that provided by an alternative policy and institutional arrangements that allow individuals more choice regarding their savings and investments.

A final point concerns the design of a supplementary pension system. Supplementary pension plans that are not fully actuarial and individualized contain elements of redistribution and risk sharing across individuals in a group, such as white-collar workers in a certain industry. The pension benefit level may be disproportionately connected to the wage level achieved at the end of a professional career. Moreover, transferring the accumulated pension assets in the case of a change in employer and/or industry may be difficult. To the extent that transferring the accumulated pension assets is difficult, the mobility of (older) workers across firms and the hiring of unemployed elderly individuals are significantly discouraged. 


\subsection{Product Market Regulations, Entry, and Competition Policy}

Excessive product market regulation deters entry, reduces growth at the firm level, and impedes growth and productivity at the aggregate level. ${ }^{37}$ Institutions matter, as shown by, for example, Gordon (2004) and Bosma and Harding (2007), who claim that the growth differences between Europe and the U.S. are explained by differences in the quality of regulations. Additionally, in Europe, considerable differences can be discerned. Shleifer et al. (2008) argue that a French legal origin (civil law) tends to weaken the incentives for innovation and the effect of innovation on growth compared with an Anglo-American common law legal origin. Therefore, regulations have a decisive impact on entry, innovation, and growth.

More precisely, compliance with regulation implies that costs are incurred, which particularly damages new and smaller firms (Glaeser and Kerr 2009). The most detrimental effects are attributed to high startup costs (Fonseca et al. 2001, 2007). In addition, regulations not only imply higher direct costs of entering a market but also lead to potentially substantial indirect effects that deter entry. As shown by Ciccone and Papaioannou (2006), Ardagna and Lusardi (2009), and Klapper and Love (2011), the positive effect associated with skills (education) diminishes considerably in more regulated countries, particularly for opportunity-based entrepreneurship. Regulations also significantly reduce the propensity for marginalized groups to start new firms. Similarly, the positive effects of knowing people who are entrepreneurs, i.e., the spillover effects associated with networks and entrepreneurial culture, become restricted. ${ }^{38}$ These effects prevail primarily with respect to opportunity- and innovation-based entrepreneurship.

Another stream of literature builds on the industrial organization tradition (Bain 1955) that centers on not only entry but also on the effects pertaining to preemption and strategic interaction (Gilbert and Newbery 1982; Laffont and Tirole 1993; Nickell 1996; Berry and Pakes 2003; Aghion et al. 2009). These models are comprehensive, incorporating the effects of competition and innovation of incumbents and new firms in the analysis. For example, Aghion et al. (2009) show that entry — or entry threats - has positive effects on the innovative behavior of incumbents near the technological frontier, whereas no similar effects are found for technological laggards. Aghion et al. call these effects the "escape-entry" effect and the "discouragement effect", and the policy implications of these effects depend on the type of industry (Aghion and Griffith 2005).

Product market regulations thus stifle competition and entry, thereby reducing growth. Even if new entrants do not display high productivity, they trigger incumbents to improve their

\footnotetext{
${ }^{37}$ See Evans and Jovanovic (1989), Geroski (1989), Blundell et al. (1999), Nickell (1996), Hurst and Lusardi (2004), Djankov et al. (2007), Fiori et al. (2007), Gentry and Hubbard (2000), Nicoletti and Scarpetta (2003), Arnold et al. (2008), Ciccone and Papaionnou (2006), and Ardagna and Lusardi (2010).

${ }^{38}$ These effects are quantified by Ardagna and Lusardi (2009). For example, the positive network effects are reduced by more than two-thirds.
} 
performance (Inklaar et al. 2008, Andersson et al. 2012). Maintaining low entry barriers becomes strategically important (Howitt 2007).

Regulations may also affect the diffusion of new findings. As Poschke (2010) argues, a more favorable regulatory system facilitates faster adoption of new technology in the U.S., thus giving U.S. producers a competitive edge over European producers, particularly in the service sectors. This result is partly attributed to weaker competition in Europe, which has less innovation and weaker incentives to adopt new technology. As shown in Figure 6, although all OECD countries have deregulated since the 1990s, there are still large cross-country variations.

Fig. 6 Product Market Regulations in a Number of Countries (Index: 0 to 6)

\section{Enclosed}

Source: Arnold, Nicoletti and Scarpetta (2011).

Similarly, if competitive forces are weakened, lower allocative efficiency in factor markets can be expected. More productive firms and sectors may not attract the production factors that are required for expansion, which will result in lower growth. These negative effects need not be linear, but they can generate disruptive and sudden effects (Arnold et al. 2011).

All in all previous research emphasizes the importance of competition and entry. Regulations that create disincentives for firms and individuals to engage in experimental and innovative activities can be expected to impede growth. Combined with rapid technological change, where competition should be understood in a dynamic rather than a static sense, conditions can change quickly and could render regulations obsolete.

\subsection{Agglomeration Economies, Housing Markets, and Infrastructure}

Spatial concentration of the people, firms, and human capital enhances productivity according to the agglomeration literature (Rosenthal and Strange 2008). The advantages of proximity arise though several means, such as the facilitation of knowledge diffusion, thecreation of communications externalities, the generation of specialization, and the reduction of transport costs.

Evidence indicates that knowledge spillovers are particularly important for more technologically sophisticated production and for contexts in which knowledge is still in a more fluid and early stage. This evidence corresponds with findings demonstrating that proximity to specific knowledge nodes, such as universities, tends to increase innovativeness. $^{39}$

The mechanisms causing knowledge diffusion and innovations (compare section 5.3) are frequent job changes and close interactions among employees. These repeated encounters drive dynamic processes, generating vertical and horizontal connections that appear in

\footnotetext{
${ }^{39}$ See, e.g., Zucker et al. (1998) and Andersson et al. (2004).
} 
productivity effects regarding the transmission of knowledge/information (Saxenian 1994; Porter 1998; Glaeser and Gottlieb 2009). Indeed, evidence also shows that firms are likely to patent more in regions characterized by higher labor mobility (Kim and Marschke 2005) and greater population density (Lööf and Nabavi 2012) .

Regarding entrepreneurship and firm location, a large literature supports a positive effect of a geographically concentrated environment. Similarly, better access to finance and services, greater flows of ideas, larger markets, less swings in demand, and lower entry costs are among the most commonly cited advantages that induce agglomeration. ${ }^{40}$ Geographical proximity seems to be critical to knowledge transmission, a process that is further intensified because density also encourages fierce competition.

Thus, innovation processes and entrepreneurial activity are largely localized processes, and innovation capabilities originate from the interplay between generic knowledge and learning processes that are embedded in the knowledge and market environment of regions. ${ }^{41} \mathrm{~A}$ critical mass seems to be required for dynamic and innovative processes to emerge. Empirical findings also suggest that innovative processes are more concentrated than inventive or production activities, enhancing the incentives for firms to locate in dense, knowledgeintensive areas (Feldman 1994; Feldman and Audretsch 1999; Paci and Usai 1999; Ejermo 2009).

Furthermore, dense environments are characterized by distinct wage and productivity premiums (Puga 2010). Glaeser and Mare (2001), for example, report a wage premium in the U.S. of 33 percent between the largest metropolitan areas and non-urban locations. Therefore, strong centripetal forces attract both individuals and firms to dense environments.

Delgado et al. (2014) show that industries belonging to strong clusters have higher employment and wage growth as well as higher growth in the number of establishments and patenting. Growth at the level of the industry or cluster also increases with the strength of related clusters in the region and with the strength of similar clusters in adjacent regions. Moreover, the study provides evidence that new regional industries emerge when a strong cluster environment exists. This evidence suggests that the existence of strong clusters in a region enhances growth opportunities in other industries and clusters.

Innovation policy must therefore include a strategy for cluster development and urbanization. Well-functioning markets where prices are allowed to reflect scarcity and preferences are necessary conditions for continued growth in dense areas-particularly in the housing market. Housing must be supported by adequate infrastructure that allows smooth transportation and commuting. If these prerequisites are absent, inherently centripetal forces may become centrifugal and may result in dispersion — or few of the potential agglomeration effects may be realized. By contrast, when different policies complement and reinforce one another, region-specific connections and institutions evolve and adapt over time in a complex

\footnotetext{
${ }^{40}$ See, e.g., Fujita et al. (1999) and Hendersson and Thisse (2004).

${ }^{41}$ See, e.g., Martin and Ottaviano (2001) and Agrawal et al. (2008).
} 
interaction that often becomes a key component of a region's competitive advantage (Gertler 2004; Wolfe and Gertler 2006).

\section{Concluding Remarks}

In the aftermath of the IT crash and the precipitous loss of market capitalization in the "new economy”, entrepreneurship was no longer heralded in policy discussion, at least in Europe. After several years, a new buzz word appeared: innovation. The U.S. launched its national innovation strategy in 2009, and the goals were lofty: “President Obama’s Strategy for American Innovation seeks to harness the ingenuity of the American people to ensure economic growth that is rapid, broad-based, and sustained. This economic growth will bring greater income, higher quality jobs, and improved quality of life to all Americans." ${ }^{42}$ In the following year, the OECD presented its innovation strategy (OECD 2010). Moreover, in the European Union, the "Innovation Union" was launched as a key component in the EU 2020 strategy. For the European Union, the tone is urgent, verging on desperation: "We need to do much better at turning our research into new and better services and products if we are to remain competitive in the global marketplace and improve the quality of life in Europe. We are facing a situation of 'innovation emergency'.,43

Innovation has understandably become a favorite concept among policy makers. In addition to avoiding the burden of previous overuse, innovation connotes novelty, modernity, and dynamism. The question concerns how to design a long-term institutional structure that is conducive to innovation and growth.

Cross-country differences in long-term economic performance are ultimately caused by differences in the rules of the game in society or the institutional system, broadly construed. Factors of production are only proximate causes of growth, whereas the ultimate causes reside in the incentive structure that encourages individual effort, entrepreneurship, and investment in physical and human capital as well as in new technology.

In reality, the interaction between various dimensions of an institutional system and entrepreneurial activity and the relationship between this interaction and innovation is highly complex and difficult to disentangle. Each country has its own bundle of formal and informal institutions that have evolved over time. The efficiency of an institutional setup depends on the complementarity of its various constitutive elements (Freeman et al. 1997; Schmidt and Spindler 2002). Moreover, entrepreneurs are not the only agents who are important for economic progress. Successful entrepreneurs who identify and exploit new ideas-thereby creating and expanding businesses - depend on many complementary agents, such as innovators, skilled workers, industrialists, venture capitalists, agents in secondary markets, and competent customers. High-impact entrepreneurship becomes impossible without these complementary competencies and inputs. Focusing solely on entrepreneurship has never been

\footnotetext{
${ }^{42}$ Cited from www.whitehouse.gov/issues/economy/innovation (accessed November 1, 2014).

${ }^{43}$ Cited from http://ec.europa.eu/research/innovation-union/index_en.cfm?pg=why (accessed November 1, 2014).
} 
a credible political strategy. Still, entrepreneurship is crucial, as a lack of entrepreneurs cannot be fully offset by an ample supply of skilled labor or an extensive capital market.

Because of the strong complementarity of the elements constituting an institutional setup, a major weakness in one element cannot easily be compensated by improvements in other elements. For example, excessive taxation of gains on stock options effectively bars the development of a vibrant VC industry. ${ }^{44}$ Thus, great benefits can be gained by identifying and eliminating institutional bottlenecks (Acs et al. 2014b).

We, however, anticipate a significant risk that future innovation policies will become fragmented and overly focused on R\&D subsidies and other support programs for high-tech firms. A suboptimal policy mix with regard to the conditions for knowledge diffusion, in contrast to knowledge accumulation, could impede countries and regions from reaching their potential growth trajectories.

Based on an evolutionary Schumpeterian view of the functioning of the economy, we instead recommend a more comprehensive approach. Our objective is to create institutional conditions that will render the national economy, as a whole, more innovative and growth oriented in the long term. The development of such institutional conditions requires tax and regulatory systems that stimulate the creation, diffusion, and productive use of knowledge in all sectors of the economy. For this purpose, we suggest several measures that collectively constitute a framework for innovation and entrepreneurship policy. This framework should focus on complementary institutions that combine to achieve two objectives:

- The accumulation, investment, and upgrading of knowledge. The policy areas involved in this objective relate to institutions that are needed to encourage high-quality education at all levels, to develop internationally leading universities and university research, to establish connections between academia and the commercial sectors, and to fund universities.

- $\quad$ The implementation of mechanisms that enable knowledge to be exploited such that growth and societal prosperity is increased. This objective involves a completely different set of institutions, such as tax policies, the regulatory burden, competition policy, and enabling policies that facilitate cluster formation. These policies create environments and strong incentives for innovation, entrepreneurial venturing, and the subsequent expansion of the most viable ventures.

We cannot define the exact components of policies that are likely to accomplish both knowledge upgrading/accumulation and knowledge diffusion, as the effect of institutions on innovation and entrepreneurship depends on a coherent design over different national and regional policy areas. But we can identify the most important institutional areas to achieve the above-mentioned objectives. We assert that the following policy areas are key to promoting long-term, sustainable growth.

\footnotetext{
${ }^{44}$ See Henrekson and Sanandaji (2014).
} 
First, a critically important and necessary condition is a high-quality education system at all levels. Such a system implies continuous evaluation of school performance and student skills and sizeable sanctions if schools underperform. Competition and diversity among schools should be encouraged but monitored and audited. Academic research must be world class in at least some areas, and the incentives for cutting-edge research must be sufficiently strong to attain this objective. Research policy should have a time perspective of a decade or more to reassure the involved agents that the government has a long-term commitment. In addition to auditing by government agencies, the instrument to achieve these goals is benchmarking with other leading nations.

Second, the quality of regulations is decisive for creating an attractive environment for innovators, entrepreneurs, and incumbent firms. Excessive red tape distorts the functioning of markets and encourages regulatory capture and rent seeking. Proposals for new regulation should be automatically dismissed unless backed by a cost-benefit analysis. Because government agencies often have considerable freedom to impose new legislation or regulations, we suggest that an independent "Regulation Committee" should have the mandate to order cost-benefit analyses from the agencies concerned. This mandate will avoid the introduction of onerous regulation, unless the benefits are convincingly shown to exceed the costs. Such authorities exist, e.g., in Canada. The mandate could also be extended to include a more general advisory function whereby interactions among regulations are analyzed. For example, strong intellectual property rights may not yield the expected results unless they are supported by adequate competition policies.

Third, a relevant incentive structure must be in place. Such an incentive structure refers to a tax system that encourages investment in education and valuable skills, entrepreneurial experimentation, and the exploitation of scale economies. The most successful entrepreneurs are highly educated. In addition, incumbents' performance depends on a well-educated labor force. Innovation and productivity relate to matching and attracting relevant skills. High taxes discourage these dynamics. Appropriately designed stock options are a powerful instrument to build firms by attracting and retaining key personnel. Capital taxes are essential to the payoffs of entrepreneurial risk taking. Again, in an increasingly globalized market, benchmarking with other countries may constitute a straightforward method to attain a competitive and wellfunctioning tax system. The tax system should be considered from both sides, namely, the costs to individuals and firms and the benefits to societal services. The societal services that a tax system provides are also part of the attractiveness of an economy.

The normative conclusions may seem trivial and easily construed. It is also tempting to look for a country that is perceived to do well on a particular aspect and to argue that a certain institutional element, which allegedly causes this fortunate outcome, should be imported. However, matters become more complicated, as each country has its own bundle of formal and informal institutions that have evolved over time. The efficiency of an institutional setup depends on the complementarity of various elements, and an isolated and ill-conceived change in one element can cause inconsistencies, rendering the entire system less efficient. Therefore, caution and humility are necessary. Still, there is no other way but to learn from the best and to be aware of the difficulties involved in importing particular policies and 
institutions from other countries. Although it is naïve to believe that one country can imitate and import ready-made institutions from other countries, there is room for learning, adoption, and adaptation. 


\section{References}

Acemoglu, D., \& Johnson, S. (2012). Why nations fail. New York: Oxford University Press.

Acs, Z.J., Audretsch, D.B., Braunerhjelm, P., \& Carlsson, B. (2009). The knowledge spillover theory of entrepreneurship. Small Business Economics, 32(1), 15-30.

Acs, Z.J., Autio, E., \& Szerb, L. (2014a). National systems of entrepreneurship: measurement issues and policy implications. Research Policy, 43(3), 476-494.

Acs, Z.J., Autio, E., \& Szerb, L. (2014b). Global Entrepreneurship and Development Index 2014. Washington, D.C.: Global Entrepreneurship and Development Institute.

Aghion, P., Akcigit, U., \& Howitt, P. (2013). What do we learn from Schumpeterian growth theory? CESIS Working Paper No. 298. Stockholm: CESIS - Centre of Excellence for Science and Innovation Studies, Royal Institute of Technology (KTH).

Aghion, P., Blundell, R., Griffith, R., Howitt, P. \& Prantl, S. (2006). The effects of entry on incumbent innovation and productivityReview of Economics and Statistics, 91(1), 20-32.

Aghion, P., \& Griffith, R. (2005). Competition and growth: Reconciling theory and evidence. Cambridge, MA: MIT Press.

Aghion, P., \& Howitt, P. (1992). A model of growth through creative destruction. Econometrica, 60(2), 323-351.

Agrawal, A., Kapur, D., \& McHail, J. (2008). How do spatial and social proximity influence knowledge flows? Evidence from patent data. Journal of Urban Economics, 64(2), 258-269.

Almeida, P. (1999). Small firms and economic growth. In Z.J. Acs, B. Carlsson, \& A.R. Thurik (Eds.), Small Business in the Modern Economy. Oxford: Blackwell.

Almeida, P., \& Kogut, B. (1997). The exploration of technological diversity and the geographic localization of innovation. Small Business Economics, 9(1), 21-31.

Andersen, T. M., \& Svarer, M. (2007). Flexicurity: labour market performance in Denmark. CESifo Economic Studies, 53(3), 389-429.

Andersson, M., Braunerhjelm, P., \& Thulin, P. (2012). Entrepreneurs, creative destruction and production: Entry by type, sector and sequence. Journal of Entrepreneurship and Public Policy, 1(2), 125-146.

Andersson, M., \& Thulin, P. (2008). Globalisering, arbetskraftens rörlighet och produktivitet. Research report 23, Globalization Council. Stockholm: Ministry of Education.

Andersson, R., Quigley, J., \& Wilhelmsson, M. (2004). University decentralization as regional policy: the Swedish experiment. Journal of Economic Geography, 4(4), 371-388.

Antonelli, C. (2007). The path dependent complexity of localized technological change: ingredients, governance and processes. London:Routledge.

Ardagna, S., \& Lusardi, A. (2009). Heterogeneity in the effect of regulation on entrepreneurship and entry size. NBER Working Paper No. 15510. Cambridge, MA: National Bureau of Economic Research (NBER).

Ardagna, S., \& Lusardi, A. (2010). Explaining international differences in entrepreneurship: the role of individual characteristics and regulatory constraints. In J. Lerner, \& A. Schoar (Eds.), International Differences in Entrepreneurship. Chicago: University of Chicago Press.

Arnold, J., Nicoletti, G., \& Scarpetta, S. (2008). Regulation, allocative efficiency and productivity in OECD countries: industry and firm-level evidence. OECD Economics Department Working Paper No. 616. Paris: OECD.

Arnold, J., Nicoletti, G., \& Scarpetta, S. (2011). Regulation, resource reallocation and productivity growth. In H. Strauss (Ed.), Productivity and growth in Europe: long-term trends, current challenges and the role of economic dynamism. EIB Papers, Vol. 11, No. 1, 90-115. Luxemburg: European Investment Bank.

Åstebro, T., Braunerhjelm, P., \& Broström, A. (2013). Does academic entrepreneurship pay? Industrial and Corporate Change, 22(1), 281-311. 
Autor, D. H., Kerr, W.R., \& Kugler, A.D. (2007). Do employment protections reduce productivity? Evidence from U.S. states. NBER Working Paper No. 12860. Cambridge, MA: National Bureau of Economic Research (NBER).

Bain, J. (1956). Barriers to new competition, their character and consequences in manufacturing industries. Cambridge, MA: Harvard University Press.

Barro, R.J. (1999). Human capital and growth in cross-country regressions. Swedish Economic Policy Review, 6(2), 237-277.

Bartelsman, E., Haltiwanger, J., \& Scarpetta, S. (2004). Microeconomic evidence of creative destruction in industrial and developing countries. World Bank, Policy Research Working Paper No. 3464.

Bassanini, A., Nunziata, L., \& Venn, D. (2009). Job protection legislation and productivity growth in OECD countries. Economic Policy, 24(58), 349-402.

Baumol, W.J. (2002). The free-market innovation machine. Princeton, NJ: Princeton University Press.

Baumol, W.J. (2004). Entrepreneurial enterprises, large established firms and other components of the free-market growth machine. Small Business Economics, 23(1), 9-23.

Baumol, W.J. (2010). The microtheory of innovative entrepreneurship. Princeton, NJ: Princeton University Press.

Béchard, J-P., \& Grégoire, D. (2005). Entrepreneurship education research revisited: the case of higher education. Academy of Management Learning and Education, 4(1), 22-43.

Berry, S., \& Pakes, A. (2003). Empirical models of entry and market structure. In R. Schmalensee \& R. Willig (Eds.), Handbook of industrial organization. Amsterdam: North Holland.

Bessen, J., \& Maskin, E. (2009). Sequential innovation, patents, and imitation. RAND Journal of Economics, 40(4), 611-635.

Blundell, R., Griffith, R., \& Van Reenen, J. (1999). Market share, market value and innovation in a panel of British manufacturing firms. Review of Economic Studies, 66(3), 529-544.

Bolton, P., \& Dewatripont, M. (2005). Contract theory. Cambridge, MA: MIT Press.

Bosma, N.S., \& Levie, J. (Eds). (2010). Global entrepreneurship monitor 2009 executive report. Babson Park, MA, Santiago de Chile, Reykjavik and London: Babson College, Universidad del Desarrollo, Reykjavík University and London Business School.

Bosma, N.S., \& Harding, R. (2007). Global entrepreneurship monitor: GEM 2006 summary results. Babson Park, MA and London: Babson College and London Business School.

Braunerhjelm, P. (Ed.) (2010). En innovationsstrategi för Sverige. Swedish Economic Forum Report 2010. Stockholm: Entreprenörskapsforum.

Braunerhjelm, P. (2011). Entrepreneurship, innovation and economic: growth interdependencies, irregularities and regularities. In D.B. Audretsch, O. Falck, \& S. Heblich (Eds.), Handbook of innovation and entrepreneurship. Cheltenham, UK and Northampton, MA: Edward Elgar.

Braunerhjelm, P. (2012). Innovation and growth. In M. Andersson, B. Johansson, \& H. Lööf (Eds.), Innovation and growth: from $R \& D$ strategies of innovating firms to economy-wide technological change. Oxford: Oxford University Press.

Braunerhjelm, P., Ding, D., \& Thulin, P. (2014). Does labor mobility foster innovation? The case of Sweden. Mimeo, presented at the Schumpeter Conference, Jena.

Braunerhjelm, P., Acs, Z.J., Audretsch, D.B., \& Carlsson, B. (2010). The missing link: knowledge diffusion and entrepreneurship in endogenous growth. Small Business Economics, 34(2), 105125.

Caballero, R.J. (2007). Specificity and the macroeconomics of restructuring. Cambridge, MA: MIT Press.

Caballero, R.J., \& Hammour, M. (2000). Creative destruction and development: institutions, crises and restructuring. NBER Working Paper No. 7849. Cambridge, MA:National Bureau of Economic Research (NBER). 
Carlsson, B. (2007). Innovation systems: a survey of the literature from a Schumpeterian perspective. In H. Hanusch \& A. Pyka (Eds.), Elgar companion to neo-schumpeterian economics. Cheltenham, UK and Northampton, MA: Edward Elgar.

Carlsson, B., Acs, Z.J., Audretsch, D.B., \& Braunerhjelm, P. (2009). Knowledge creation, entrepreneurship, and economic growth: a historical review. Industrial and Corporate Change, 18(6), 1193-1229.

Carree, M., \& Thurik, A.R. (2010). The impact of entrepreneurship on economic growth. In Z.J. Acs, \& D.B. Audretsch (Eds.), Handbook of entrepreneurship research. New York and London: Springer.

Cassiman, B., Veugelers, R., \& Arts, S. (2011). Tracing the effect of links between science and industry: the role of researcher interaction and mobility between firms and research organizations. IESE Working Paper. Navarra: IESE Business School.

Chetty, R., \& Saez, E. (2005). ”Dividend taxes and corporate behavior: evidence from the 2003 dividend tax cut. Quarterly Journal of Economics, 120(3), 791-833.

Ciccone, A., \& Papaioannou, E. (2006). Red tape and delayed entry. CEPR Discussion Paper 5996. London: Centre for Economic Policy Research (CEPR).

Coase, R.H. (1960). The problem of social cost. Journal of Law and Economics, 3(October), 1-44.

Cullen, J.B., \& Gordon, R.H. (2007). Taxes and entrepreneurial risk-taking: theory and evidence in the U.S. Journal of Public Economics, 91(7-8), 1479-1505.

Cumming, D. (2005). Agency costs, institutions, learning, and taxation in venture capital contracting. Journal of Business Venturing, 20(5), 573-622.

Da Rin, M., Nicodano, G., \& Sembenelli, A. (2006). Public policy and the creation of active venture capital markets. Journal of Public Economics, 90(8), 1699-1723.

Davis, S.J., \& Henrekson, M. (1999). Explaining national differences in the size and industry distribution of employment. Small Business Economics, 12(1), 59-83.

Delgado, M., Porter, M.E. \& Stern, S. (2014). Clusters, convergence, and economic performance. Research Policy, 43(10), 1785-1799.

Denison, E. F. (1968). Measuring the economic contribution of education and the 'residual' to economic growth. In J. Bowman (Ed.), Readings in the economics of education. Paris: UNESCO.

Desai, M., Gompers, P., \& Lerner, J. (2003). Institutions, capital constraints and entrepreneurial firm dynamics: evidence from europe. NBER Working Paper No. 10165. Cambridge, MA:National Bureau of Economic Research (NBER).

De Soto, H. (2000). The mystery of capital: why capitalism triumphs in the west and fails everywhere else. New York: Basic Books.

Djankov, S., McLiesh, C., \& Shleifer, A. (2007). Private credit in 129 countries. Journal of Financial Economics, 84(2), 299-329.

Djankov, S., La Porta, R., Lopes de Silanes, F., \& Schleifer, A. (2002). The regulation of entry. Quarterly Journal of Economics, 117(1), 1-37.

Domar, E.D., \& Musgrave, R.A. (1944). Proportional income taxation and risk-taking. Quarterly Journal of Economics, 48(3), 388-422.

Dosi, G. (1982). Technological paradigns and technological trajectories. A suggested interpretation of the determinants and directions of technical change. Research Policy, 11(3),147-162.

Edquist, C. (2011). Design of innovation policy through diagnostic analysis: identification of systemic problems (or failures). Industrial and Corporate Change, 20(6), 1-29.

Eliasson, G. (1996). Firm objectives, controls and organization: the use of information and the transfer of knowledge within the firm. Dordrecht, NL: Kluwer Academic Publishers.

Ejermo, O. (2009). Regional innovation measured by patent data - does quality matter? Industry and Innovation, 16(2), 141-165.

Engström, P., \& Holmlund, B. (2009). Tax evasion and self-employment in a high-tax country: Evidence from Sweden. Applied Economics, 41(19), 2419-2430. 
Evans, D.S., \& Leighton, L.S. (1989). Some empirical aspects of entrepreneurship. American Economic Review, 79(3), 519-535.

Feldman, M. (1994). The geography of innovations. Dordrecht and Boston: Kluwer Academic Publishers.

Feldman, M.P., \& Audretsch, D.B. (1999). Innovation in cities: science-based diversity, specialization and localized competition. European Economic Review, 43(2), 409-429.

Feldman, M., Hadjimichael, T., Kemeny, T., \& Lanahan, L. (2015). The logic of economic development: a definition and model for investment. Environment and Planning C: Government and Policy, in press.

Fenn, G., Liang, N., \& Prowse, S. (1995). The economics of the private equity market. Washington, D.C.: Board of Governors of the Federal Reserve System.

Fiori, G., Nicoletti, G., Scarpetta, S., \& Schiantarelli, F. (2007). Employment outcomes and the interactions between product and labor market deregulation: are they substitutes or complements? Working Paper No. 663. Boston: Boston College.

Fonseca, R., Lopez-Garcia, P., \& Pissarides, C.A. (2001). Entrepreneurship, start-up costs and employment. European Economic Review, 45(4-6), 692-705.

Fonseca, R., Michaud, P-C., \& Sopraseuth, T. (2007). Entrepreneurship, wealth, liquidity constraints and start-up costs. Comparative Labor Law \& Policy Journal, 28(4), 637-674.

Freeman, C. (1987). Technology policy and economic performance: lessons from Japan. London: Pinter Publishers.

Freeman, R.B., Swedenborg, B., \& Topel, R. (2010). Introduction. In R.B. Freeman, B. Swedenborg, \& R. Topel (Eds.), Reforming the welfare state: recovery and beyond. Chicago: University of Chicago Press.

Fujita, M., Krugman, P.R., \& Venables, A.J. (1999). The spatial economy: cities, regions and international trade. Cambridge, MA: MIT Press.

Gault, F. (2013). Innovation indicators and measurement: an overview. In F. Gault (Ed.), Handbook of innovation indicators and measurement (pp. 3-37). Cheltenham, UK and Northampton, MA: Edward Elgar.

Gentry, W.M., \& Hubbard, R.G. (2000). Tax policy and entrepreneurial entry. American Economic Review, 90(2), 283-287.

Geroski, P. (1989). Entry, innovation and productivity growth. Review of Economics and Statistics, 71(4), 572-578.

Gertler, M.S. (2004). Manufacturing culture: the institutional geography of industrial practice. Oxford: Oxford University Press.

Gilbert, R.J., \& Newbery, D.M.G. (1982). Preemptive patenting and the persistence of monopoly. American Economic Review, 72(3), 514-526.

Gilson, R.J., \& Schizer, D.M. (2003). Understanding venture capital structure: a tax explanation for convertible preferred stock. Harvard Law Review, 116(3), 874-916.

Glaeser, E.L., \& Kerr, W.R. (2009). Local industrial conditions and entrepreneurship: how much of the spatial distribution can we explain? Journal of Economics and ManagementStrategy, 18(3), 623-633.

Glaeser, E.L., \& Maré, D.C. (2001). Cities and skills. Journal of Labor Economics, 19(2), 316-342.

Glaeser, E.L., \& Gottlieb, J.D. (2009). The wealth of cities: agglomeration and spatial equilibrium in the United States. NBER Working Paper No. 14806. Cambridge, MA: National Bureau of Economic Research (NBER).

Gompers, P.A., \& Lerner, J. (2001). The money of invention: how venture capital creates new wealth. Cambridge, MA: Harvard Business School Press.

Gordon, R.J. (2004). Why was Europe left at the station when America's productivity locomotive departed? NBER Working Paper No. 10661. Cambridge, MA: National Bureau of Economic Research (NBER). 
Gordon, R.H., \& Lee, Y. (2001). Do taxes affect corporate debt policy? evidence from U.S. corporate tax return data. Journal of Public Economics, 82(2), 195-224.

Gross, D.M., \& Ryan, M. (2008). FDI location and size: does employment protection legislation matter? Regional Science and Urban Economics, 38(6), 590-605.

Grossman, G., \& Helpman, E. (1991). Quality ladders in the theory of growth. Review of Economic Studies, 58(1), 43-61.

Halabisky, D., Dreessen, E., \& Parsley, C. (2006). Growth in firms in Canada, 1985-1999. Journal of Small Business and Entrepreneurship, 19(3), 255-268.

Hall, B.H. (2011). Using productivity growth as an innovation indicator. Report for the High Level Panel on Measuring Innovation. Brussels: DG Research, European Commission.

Hall, R.E., \& Woodward, S.E. (2010). The burden of the nondiversifiable risk of entrepreneurship. American Economic Review, 100(3), 1163-1194.

Haltiwanger, J., Jarmin, R.S., \& Miranda, C. (2013). Who creates jobs? Small versus large versus young. Review of Economics and Statistics, 95(2), 347-361.

Henderson, J.V., \& Thisse, J.F. (Eds.) (2004). Handbooks of regional and urban economics. Amsterdam: Elsevier.

Henrekson, M., \& Johansson, D. (2009). Competencies and institutions fostering high-growth firms. Foundations and Trends in Entrepreneurship, 5(1), 1-82.

Henrekson, M., \& Rosenberg, N. (2001). Designing efficient institutions for science-based entrepreneurship: lessons from the U.S. and Sweden. Journal of Technology Transfer, 26(3), 207-231.

Henrekson, M., \& Sanandaji, T. (2014a). Small business activity does not measure entrepreneurship. Proceedings of the National Academy of Sciences of the United States of America (PNAS), 111(5), 1760-1765.

Henrekson, M., \& Sanandaji, T. (2016). Owner-level taxes and business activity. Foundations and Trends in Entrepreneurship, forthcoming.

Holcombe, R.G. (2003). The origins of entrepreneurial opportunities. Review of Austrian Economics, 16(1), 25-43.

Howitt, P. (2007). Innovation, competition and growth: a Schumpeterian perspective on Canada's economy. C.D. Howe Institute Commentary 246. Toronto.

Hoti, S., McAleer, M., \& Slottje, D. (2006). Intellectual property litigation in the USA. Journal of Economic Surveys, 20(4), 715-729.

Huizinga, H., Laeven, L., \& Nicodeme, G. (2008). Capital structure and international debt shifting. Journal of Financial Economics, 88(1), 80-118.

Hung, S-C., \& Whittington, R. (2011). Agency in national innovation systems: institutional entrepreneurship and the professionalization of Taiwanese IT. Research Policy, 40(4), 526-538.

Hurst, E., \& Lusardi, A. (2004). Liquidity constraints, household wealth and entrepreneurship. Journal of Political Economy, 112(2) 319-347.

Inklaar, R., Timmer, M.P., \& van Ark, B. (2008). Market services productivity across Europe and the US. Economic Policy, 23(53), 139-194.

Jacobsson, S., Sjöberg, C., \& Wahlström, M. (2001). Alternative specifications of the institutional constraint to economic growth - or why is there a shortage of computer and electronic engineers and scientists in Sweden? Technology Analysis and Strategic Management, 13(2), 179-193.

Javorcik, B.S., Özden, Ç., Spatareanu, M., \& Neagu, C. (2006). Migrant networks and foreign direct investment. World Bank Policy Research Working Paper No. 4654. Washington, D.C.: World Bank

Jones, C.I. (1995). R\&D-based models of economic growth. Journal of Political Economy, 103(4), 759-784.

Jones, C.I. (2011). Intermediate goods and weak links in the theory of economic development. American Economic Journal: Macroeconomics, 3(2), 1-28. 
Jorgenson, D.W., \& Landau, R. (Eds.) (1993). Tax reform and the cost of capital: An international comparison. Washington, D.C.: Brookings.

Kaiser, U., Kongsted, H.C., \& Rønde, T. (2015). Does the mobility of R\&D labor increase innovation? Journal of Economic Behavior \& Organization, 110(2), 91-105.

Kim, J., \& Marschke, G. (2005). Labor mobility of scientists, technological diffusion, and the firm's patenting decision. RAND Journal of Economics, 36(2), 298-317.

King, M.A., \& Fullerton, D. (1984). The taxation of income from capital: a comparative study of the United States, the United Kingdom, Sweden and West Germany. Chicago: University of Chicago Press.

Klapper, L., \& Love, I. (2011). Entrepreneurship and development: the role of information asymmetries. World Bank Economic Review, 25(3), 448-455.

Klienknecht, A. (1989). Firm size and innovation. Small Business Economics, 1(3), 215-222.

Knight, F.H. (1921). Risk, uncertainty and profit. Boston, MA: Houghton Mifflin.

Kugler, A., \& Pica, G. (2008). Effects of employment protection on worker and job flows: evidence from the 1990 Italian reform. Labour Economics,15(1), 78-95.

Kuratko, D. (2005). The emergence of entrepreneurship education: development, trends, and challenges. Entrepreneurship: Theory \& Practice, 29(5), 577-597.

Laffont, J-J., \& Tirole, J. (1993). A theory of incentives and regulation. Cambridge, MA: MIT Press.

Lazear, E.P. (2005). Entrepreneurship. Journal of Labor Economics, 23(4), 649-680.

Lerner, J. (2009). Boulevard of broken dreams: why public efforts to boost entrepreneurship and venture capital have failed - and what to do about it. Princeton, NJ: Princeton University Press.

Levine, R. (2005). Finance and growth: theory and evidence. In P. Aghion \& S. Durlauf (Eds.), Handbook of economic growth. Amsterdam: Elsevier.

List, F. (1841). Das nationale system der politischen ökonomie. Basel: Kyklos (English translation: (1841), The national systems of political economy, London: Longmans, Green and Co.)

Long, J.E. (1982). Income taxation and the allocation of market labour. Journal of Labor Research, 3(3), 259-276.

Lööf, H., \& Nabavi, P. (2012). Increasing return to smart cities. Working Paper Series in Economics and Institutions of Innovation. Stockholm: CESIS - Centre of Excellence for Science and Innovation Studies, Royal Institute of Technology (KTH).

Lundvall, B-Å. (1992). National systems of innovation: towards a theory of innovation and interactive learning. London, UK: Pinter.

Malerba, F., \& Orsenigo, L. (1996). The dynamics and evolution of industries. Industrial and Corporate Change, 5(1), 51-87.

Malerba, F., \& Orsenigo, L. (2000). Knowledge, innovation activities and industrial evolution. Industrial and Corporate Change, 9(2), 289-313.

Martin, J.P., \& Scarpetta, S. (2012). Setting it right: employment protection, labour reallocation and productivity. De Economist, 160(2), 89-116.

Martin, P., \& Ottaviano, G. (2001). Growth and agglomeration. International Economic Review, 42(4), 947-968.

Micco, A., \& Pagés, C. (2006). The economic effects of employment protection: evidence from international industry-level data. IZA Discussion Paper No. 2433. Bonn: Institute for the Study of Labor (IZA).

Michaelas, N., Chittenden, F., \& Poutziouris, P. (1999). financial policy and capital structure choice in UK SMEs: empirical evidence from company panel data. Small Business Economics, 12(2), 113130.

Misher, N. (1984). Tax consequences of exercising an incentive stock option with stock of the granting corporation. The Tax Executive, July, 357-363.

Nelson, R.R., \& Winter, S.G. (1982). An evolutionary theory of economic change. Cambridge: Cambridge University Press. 
Nickell, S.J. (1996). Competition and corporate performance. Journal of Political Economy, 104(4), 724-746.

Nicoletti, G., \& Scarpetta, S. (2003). Regulation, productivity and growth: OECD evidence. Economic Policy, 18, 11-72.

North, D.C. (1990). Institutions, institutional change and economic performance. Cambridge:

Cambridge University Press.

OECD (1998). Fostering entrepreneurship. Paris: OECD.

OECD (2010). The OECD innovation strategy: getting a head start on tomorrow. Paris: OECD.

Orsenigo, L. (2009). Clusters and clustering in biotechnology: stylised facts, issues and theories. In P. Braunerhjelm \& M.P. Feldman (Eds.). Cluster genesis. Oxford: Oxford University Press.

Ortega-Argilés, R., Vivarelli, M., \& Voight, P. (2009). R\&D in SMEs: a paradox? Small Business Economics, 33(1), 3-11.

Paci, R., \& Usai, S. (1999). Externalities, knowledge spillovers and the spatial distribution of innovation. GeoJournal, 49(4), 381-390.

Peltzman, S. (1976). Toward a more general theory of regulation. Journal of Law and Economics, 19(2), 211-240.

Pestieau, P., \& Possen, U.M. (1991). Tax evasion and occupational choice. Journal of Public Economics, 45(1), 105-125.

Pigou, A.C. (1938). The economics of welfare. Fourth edition. London: MacMillan.

Porter, M. (1998). On competition. Boston: Harvard Business School Press.

Poschke, M. (2010). The regulation of entry and aggregate productivity. Economic Journal, 120(549), 1175-1200.

Poschke, M. (2013). Who becomes an entrepreneur? Labor market prospects and occupational choice. Journal of Economic Dynamics and Control, 37 (3), 693-710.

Powell, W.W., Koput, K.W., \& Smith-Doerr, L. (1996). Interorganizational collaboration and the locus of innovation: networks of learning in biotechnology. Administrative Science Quarterly, 41(1), 116-145.

Puga, D. (2010). The magnitude and causes of agglomeration economies. Journal of Regional Science, 50(1), 203-219.

Robson, M. T., \& Wren, C. (1999). Marginal and average tax rates and the incentive for selfemployment. Southern Economic Journal 65(4), 757-773.

Rodrik, D., Subramanian, A., \& Trebbi, F. (2004). Institutions rule: the primacy of institutions over geography and integration in economic development. Journal of Economic Growth, 9(2), 131165.

Romer, P.M. (1986). Increasing returns and long-run growth. Journal of Political Economy, 94(5), 1002-1038.

Romer, P.M. (1990). Endogenous technological change. Journal of Political Economy, 98(5), S71S102.

Rosen, H.S. (2005). Entrepreneurship and taxation: empirical evidence. In V. Kanniainen \& C. Keuschnigg (Eds.), Venture capital, entrepreneurship and public policy. Cambridge, MA: MIT Press.

Rosenberg, N. (2000). American universities as endogenous institutions. Ch. 3 in Schumpeter and the endogeneity of technology: some american perspectives. London: Routledge.

Rosenthal, S.S., \& Strange, W.C. (2008). The attenuation of human capital spillovers. Journal of Urban Economics, 64(2), 373-389.

Rothwell, J. (2013). The hidden STEM economy: The Metropolitan Policy Program at Brookings. Washington, D.C.: Brookings.

Rothwell, R., \& Zegveld, W. (1982). Innovation and the small and medium-sized firm. London: Pinter Publishers.

Rydqvist, K., Spizman, J., \& Strebulaev, I. (2014). Government policy and ownership of equity securities. Journal of Financial Economics, 111(1), 70-85. 
Sanandaji, T. (2011). Essays in entrepreneurship policy. PhD Dissertation in Public Policy. Chicago: Irving B. Harris Graduate School of Public Policy Studies, University of Chicago.

Sandström, C., Wennberg, K., Wallin, M., \& Zherlygina, Y. (2014). Public policy for academic entrepreneurship: a review and critical discussion. Mimeo. Royal Institute of Technology and Stockholm School of Economics.

Saxenian, A. (1994). Regional advantage: Culture and competition in Silicon Valley and Route 128. Cambridge, MA: Harvard University Press.

Scarpetta, S., \& Tressel, T. (2004). Boosting productivity via innovation and adoption of new technologies: any role for labor market institutions? World Bank Policy Research Working Paper No. 29144. Washington, D.C.: World Bank.

Scherer, F.M. (1965). Firm size, market structure, opportunity and the output of patented innovations. American Economic Review, 55(5), 1097-1125.

Schmidt, R.H., \& Spindler, G. (2002). Path dependence, corporate governance and complementarity. International Finance, 5(3), 311-333.

Segerstrom, P. (1991). Innovation, imitation and economic growth. Journal of Political Economy, 99(4), 807-827.

Shleifer, A., Lopes-de-Silanes, F., \& La Porta, R. (2008). Economic consequences of legal origins. Journal of Economic Literature, 46(2), 285-332.

Sinn, H.W. (1996). Social insurance, incentives and risk taking. International Tax and Public Finance, 3(3), 259-280.

Solow, R.M. (1957). Technical change and the aggregate production function. Review of Economics and Statistics, 39(3), 312-320.

Song, J., Almeida, P., \& Wu, G. (2003). Learning-by-hiring: when is mobility more likely to facilitate interfirm knowledge transfer? Management Science, 49(4), 351-365.

Stigler, G.J. (1971). The theory of economic regulation. Bell Journal of Economics and Management Science, 2(1), 3-21.

Thurik, A.R., \& Tessensohn, T. (2012). The relationship between different kinds of nascent entrepreneurship and the business cycle. In P. Braunerhjelm (Ed.), Entrepreneurship norms and the business cycle. Stockholm: Swedish Entrepreneurship Forum.

Tullock, G. (1969). A simple algebraic logrolling model. American Economic Review, 60(3), 419-426.

Wennekers, S., \& A.R. Thurik (1999). Linking entrepreneurship and economic growth. Small Business Economics, 13(1), 27-55.

Winter, S.G. (1964). Economic 'natural selection' and the theory of the firm. LEM Chapters Series, Yale Economic Essays, pp. 225-272.

Winter, S.G. (1984). Schumpeterian competition in alternative technological regimes. Journal of Economic Behavior and Organization, 5(3-4), 287-320.

Wolfe, D.A., \& Gertler, M.S. (2006). Local antecedents and trigger events: policy implications of path dependence for cluster formation. In P. Braunerhjelm \& M. Feldman (Eds.), Cluster genesis. technology-based industrial development. Oxford: Oxford University Press.

Zucker, L.G., Darby, M.R., \& Brewer, M.B. (1998). Intellectual human capital and the birth of U.S. biotechnology enterprises. American Economic Review, 88(1), 290-306. 
Figure 1: Economic Growth and the Rate of Innovation in EU Countries, 2006-2010.

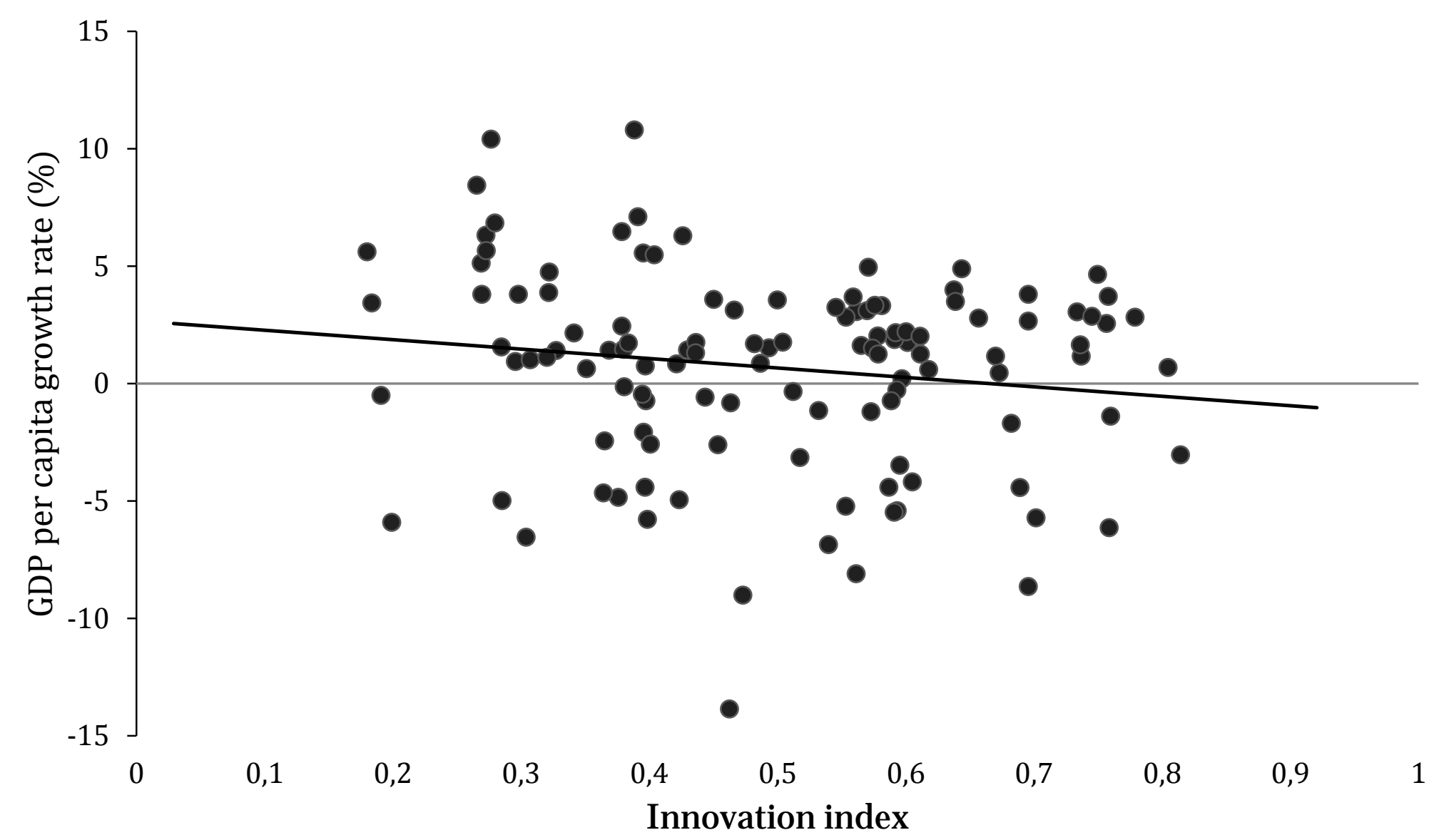

Source: Braunerhjelm (2012). 
Figure 2 From Educational Choice to Knowledge-Based Entrepreneurship.

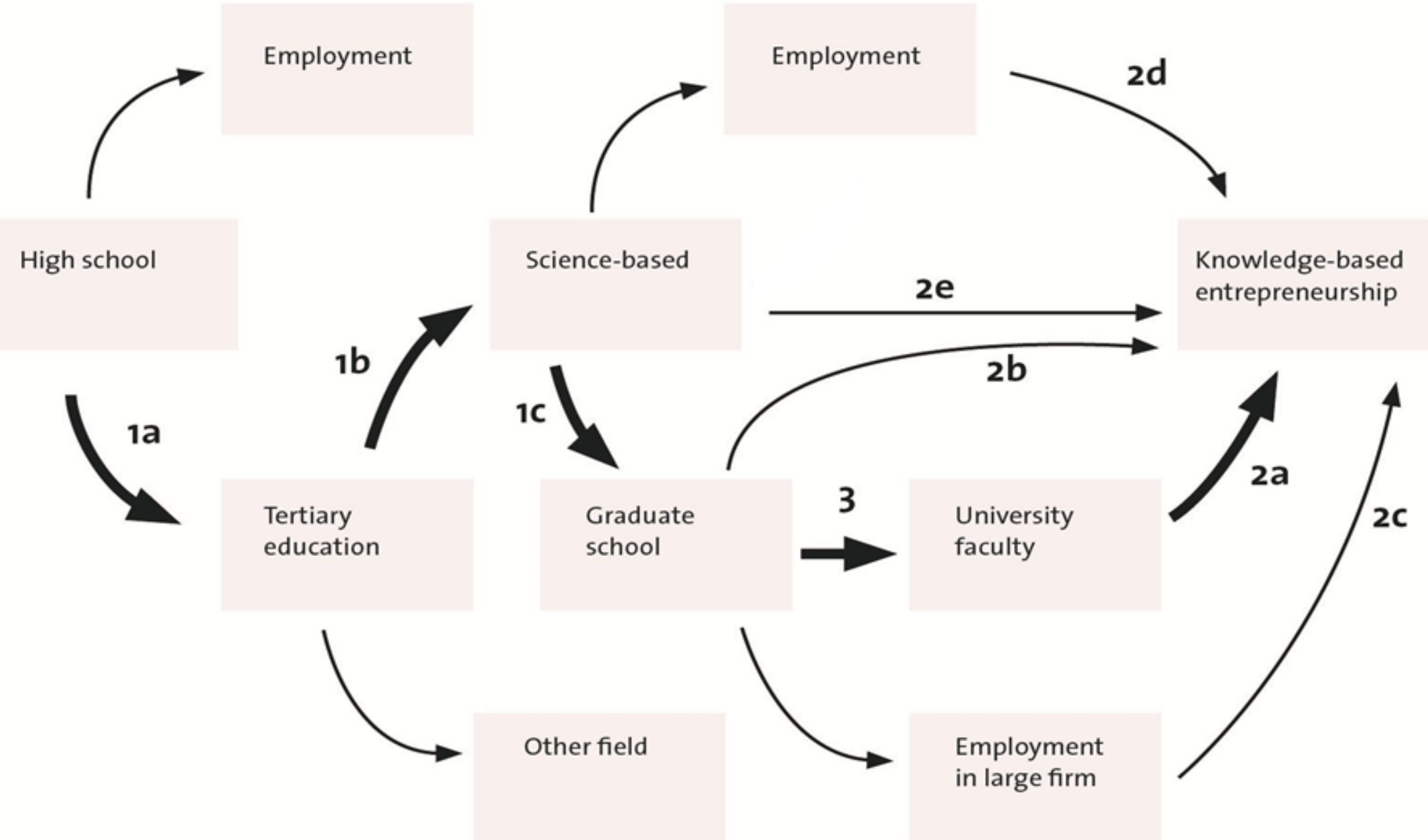

Source: Adapted from Henrekson and Rosenberg (2001). 
Figure 3 The Roles and Interaction of Different Agents in the Commercialization Process.

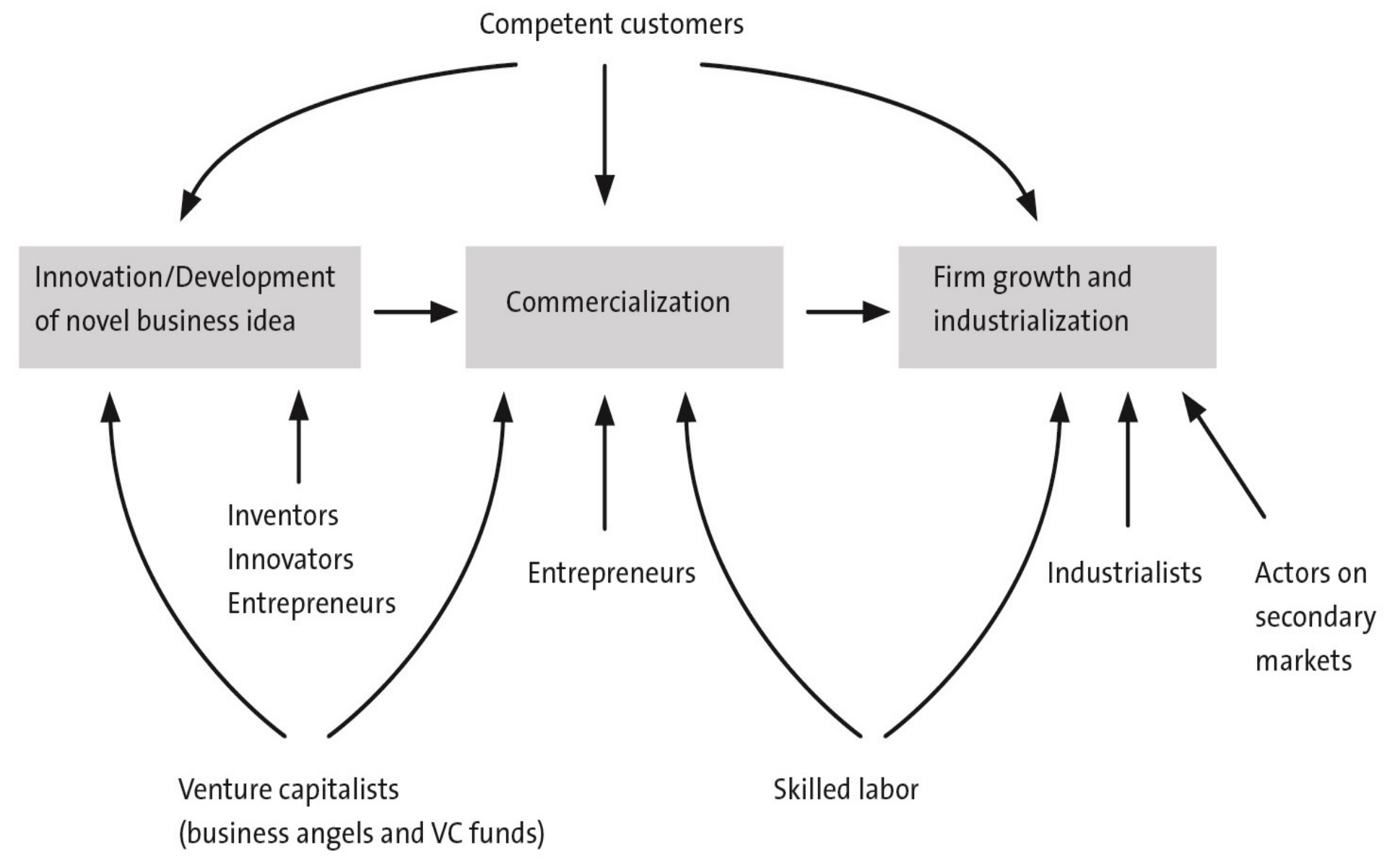


Figure 4 Central Phases in the Evolution of an Entrepreneurial Firm.

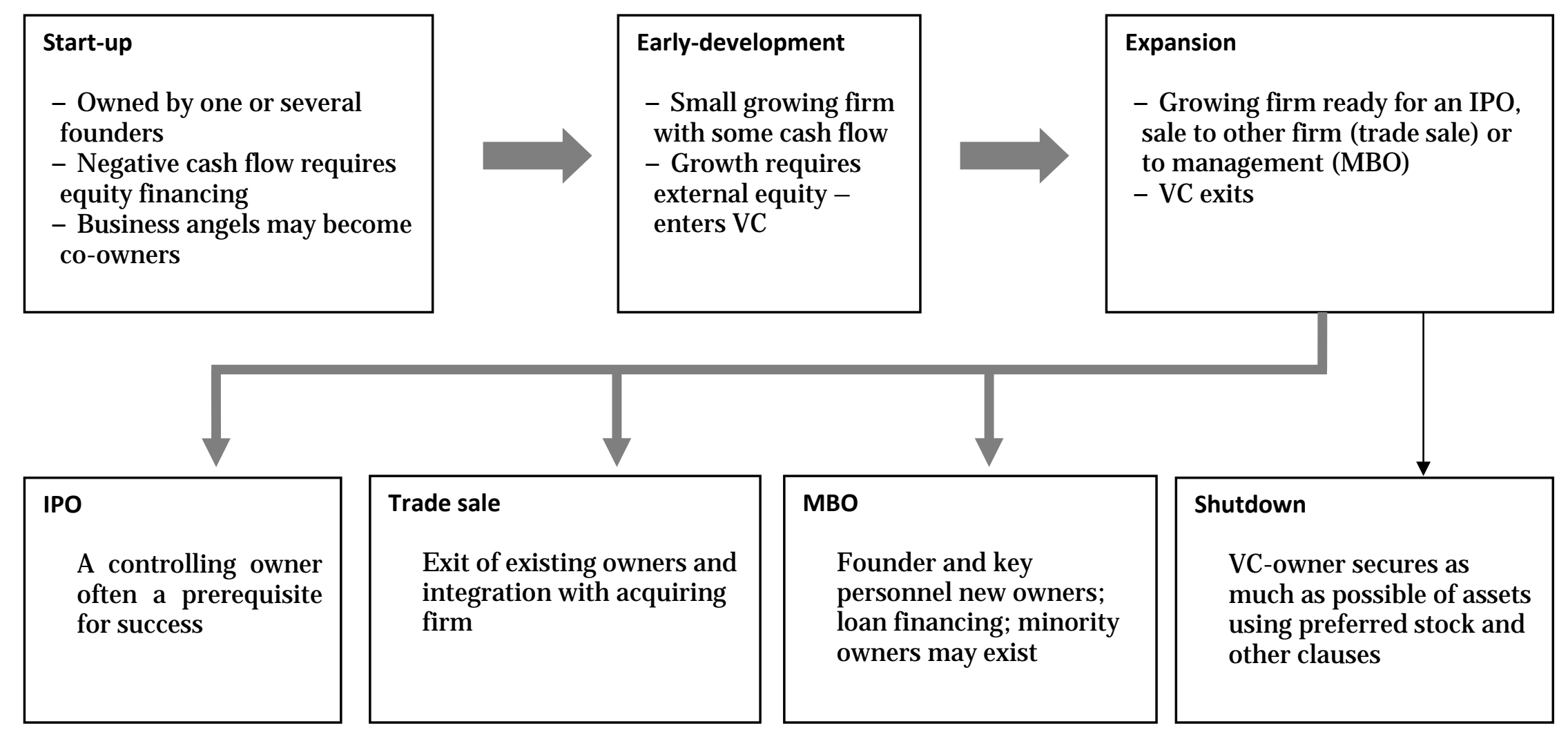

Source: Henrekson and Sanandaji (2016). 
Figure 5 Strictness of Employment Protection and High-Growth Expectation Early-Stage Entrepreneurship.

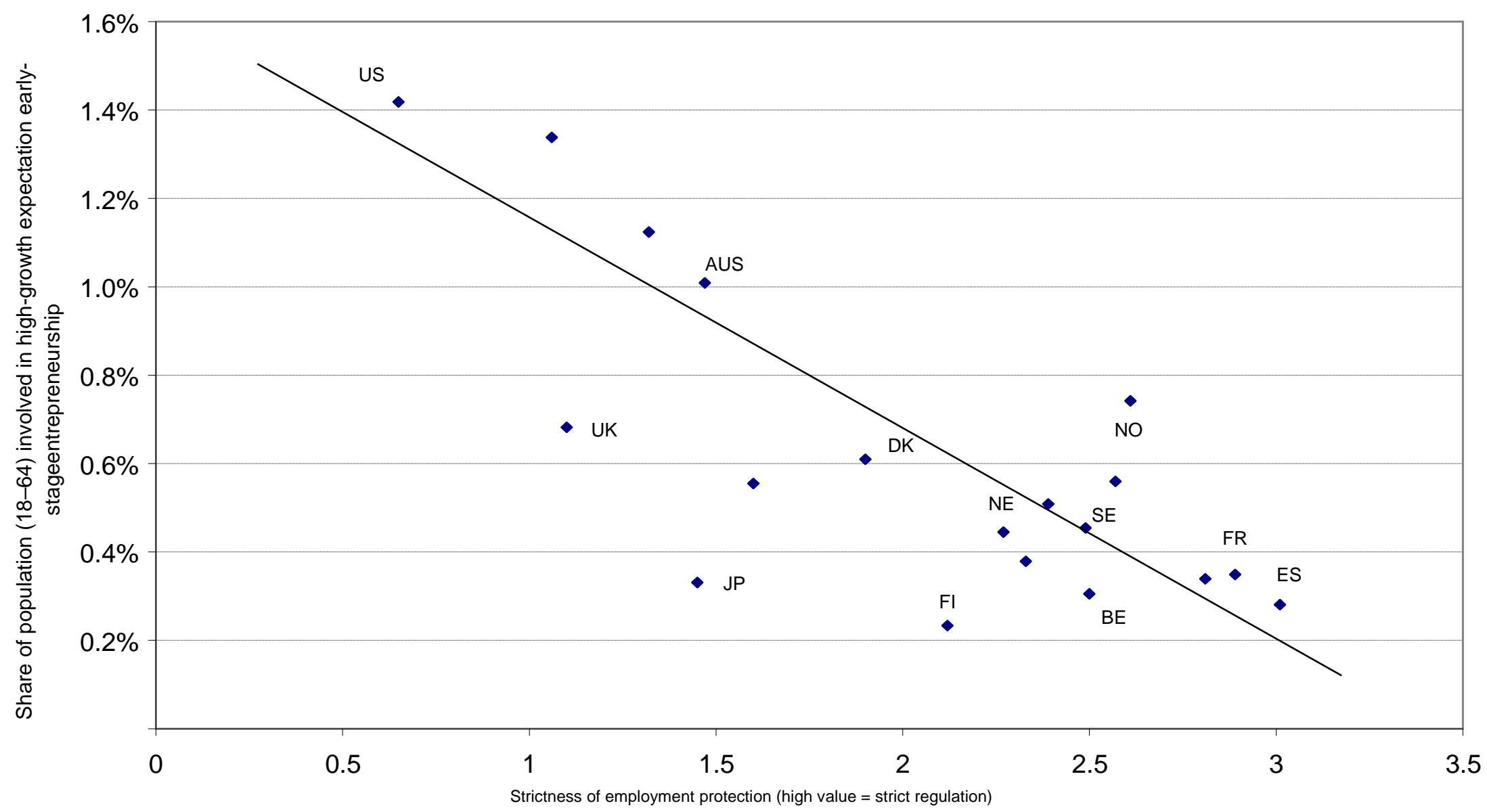

Note: Employment protection refers to the 2004 OECD index (version 2), high-growth expectation early-stage entrepreneurship is the average over the 2004-2009 period according to the Global Entrepreneurship Monitor (GEM). $\mathrm{R}^{2}=0.57$.

Source: Bosma and Levie (2010). 
Figure 6: Product Market Regulations in a Number of Countries (Index: 0 to 6).

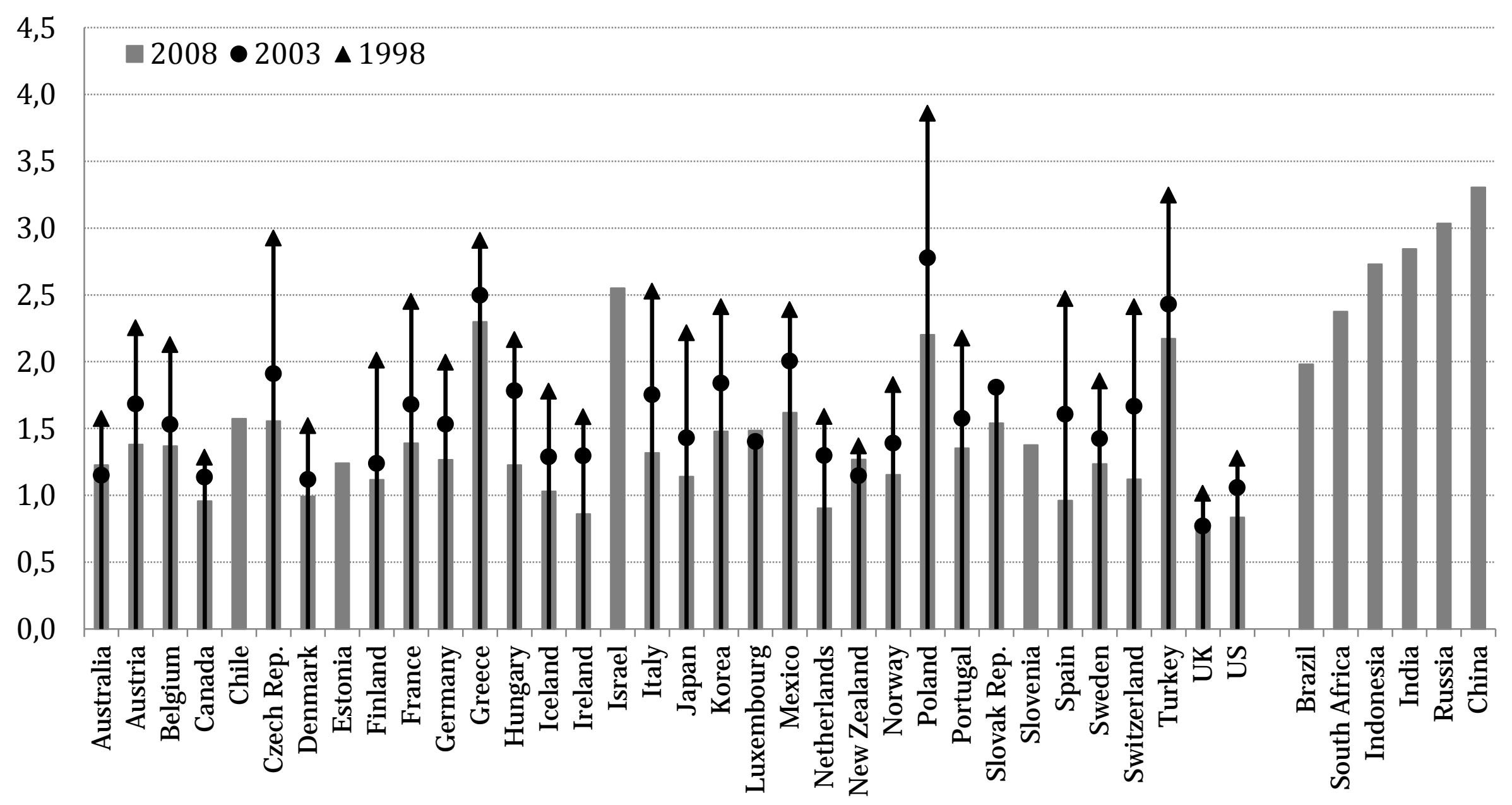

Source: Arnold, Nicoletti and Scarpetta (2011) 